Natural Hazards and Earth System Sciences, 6, 1-20, 2006

SRef-ID: 1684-9981/nhess/2006-6-1

European Geosciences Union

(c) 2006 Author(s). This work is licensed

under a Creative Commons License.

\title{
Evidence of slope instability in the Southwestern Adriatic Margin
}

\author{
D. Minisini ${ }^{1,2}$, F. Trincardi ${ }^{1}$, and A. Asioli ${ }^{3}$ \\ ${ }^{1}$ Istituto di Scienze del Mare, ISMAR-CNR, Via Gobetti 101, 40129 Bologna, Italy \\ ${ }^{2}$ Dipartimento di Scienze della Terra e Geologico-Ambientali, Univ. di Bologna, Via Zamboni 67, 40127 Bologna, Italy \\ ${ }^{3}$ Istituto di Geoscienze e Georisorse, IGG-CNR, C.so Garibaldi 37, 35137 Padova, Italy
}

Received: 29 August 2005 - Revised: 15 November 2005 - Accepted: 16 November 2005 - Published: 2 January 2006

Part of Special Issue "Tsunami hazard from slope instability"

\begin{abstract}
The Southwestern Adriatic Margin (SAM) shows evidence of widespread failure events that generated slide scars up to $10 \mathrm{~km}$ wide and extensive slide deposits with run out distances greater than $50 \mathrm{~km}$. Chirp-sonar profiles, side-scan sonar mosaics, multibeam bathymetry and sediment cores document that the entire slope area underwent repeated failures along a stretch of $150 \mathrm{~km}$ and that masstransport deposits, covering an area of $3320 \mathrm{~km}^{2}$, are highly variable ranging from blocky slides to turbidites, and lay on the lower slope and in the basin. The SAM slope between $300-700 \mathrm{~m}$ is impacted by southward bottom currents shaping sediment drifts (partly affected by failure) and areas of dominant erosion of the seafloor. When slide deposits occur in areas swept by bottom currents their fresh appearence and their location at seafloor may give the misleading impression of a very young age. Seismic-stratigraphic correlation of these deposits to the basin floor, however, allow a more reliable age estimate through sediment coring of the post-slide unit. Multiple buried failed masses overlap each other in the lower slope and below the basin floor; the most widespread of these mass-transport deposits occurred during the MIS 2-glacial interval on a combined area of $2670 \mathrm{~km}^{2}$. Displacements affecting Holocene deposits suggest recent failure events during or after the last phases of the last postglacial eustatic rise. Differences in sediment accumulation rates at the base or within the sediment drifts and presence of downlap surfaces along the slope and further in the basin may provide one or multiple potential weak layers above which widespread collapses take place. Neotectonic activity and seismicity, together with the presence of a steep slope, represent additional elements conducive to sediment instability and failure along the SAM. Evidence of large areas still prone to failure provides elements of tsunamogenic hazard.
\end{abstract}

Correspondence to: D. Minisini

(daniel.minisini@ismar.cnr.it)

\section{Introduction}

Offshore earthquakes and submarine mass failures represent the main mechanism capable to generate tsunami that constitute potential hazards to coastal communities (Synolakis et al., 1997). In some cases it proves difficult to differentiate tsunami that are generated by earthquakes from those generated by mass-failure events (Hasegawa and Kanamori, 1987; Julian et al., 1998; Geist, 2000). However, submarine mass failure is widely recognized as a complementary mechanism in the generation of tsunami (Tappin et al., 2001). Wellknown catastrophic events, such as the 1946 tsunami in the Aleutians Islands, are generated by earthquakes but appear much larger than expected solely on the basis of the seismic event; this evidence supports the notion that tsunami can result also or be amplified by earthquake-triggered landslides rather than pure seismic shocks (Tappin et al., 1999; Fryer at al., 2004). In these cases, submarine failure may provide a mechanism to enhance the tsunami wave with respect to what would be generated solely by pure co-seismic dislocation (Tappin et al., 2001; Synolakis et al., 2002). In some cases, tsunami are known to occur in response to sediment failure only, in the lack of a concurrent seismic shock (Malinverno et al., 1988; Gardner, 2001).

Typically, tsunami caused by mass failure impact on geographically more confined areas, even though they may result more devastating compared to those generated by earthquakes (Schwab et al., 1993; Tappin et al., 2001; Lee et al., 2003). The latter mechanism results in tsunami of typically greater wavelengths and longer periods (Tappin et al., 2001). The Papua New Guinea event in 1998, is one of the best documented examples of tsunami related to mass failure, and emphasizes how submarine mass failures can amplify the impact of earthquakes of relatively moderate size (Tappin et al., 2001; Synolakis et al., 2002). Submarine failures occur preferentially in areas of high sediment accumulation such as fjords, deltas, volcanic islands, submarine canyons and continental slopes (Hampton et al., 1996). 


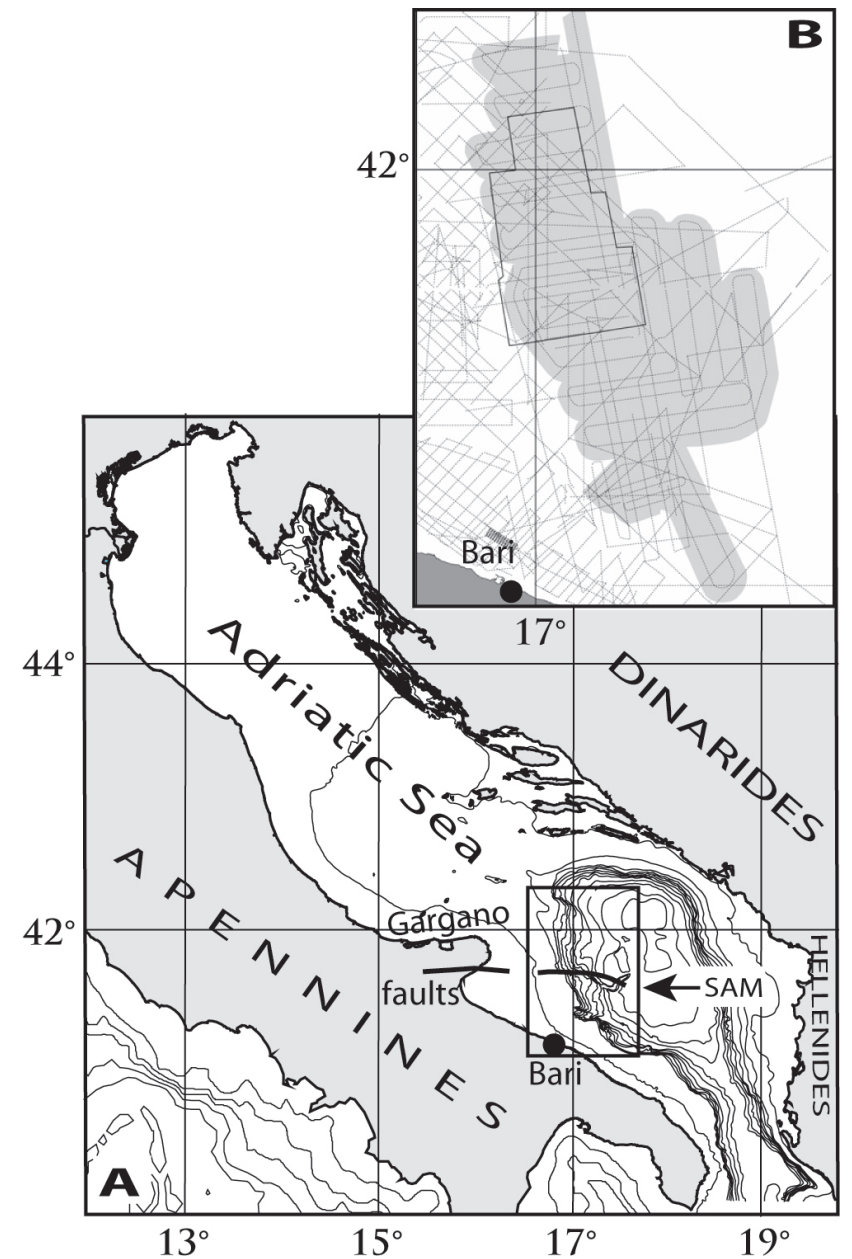

Fig. 1. (A): location of the Sothwestern Adriatic Margin (SAM) in the Adriatic Sea, Central Mediterranean Sea (bathymetric contour intervals are every $100 \mathrm{~m}$ ). (B): data base: Chirp-sonar profiles (dashed lines), TOBI side-scan sonar mosaic (grey pattern) and multibeam swath bathymetry (solid black box). B represents the SAM area shown in Fig. 2.

The Southwestern Adriatic Margin (SAM), in southern Italy (Fig. 1a), is a seismically active area repeatedly impacted by large tsunami in historical times (Tinti et al., 1995) where new multibeam bathymetric data, TOBI side-scansonar mosaics, Chirp-sonar profiles and sediment cores reveal widespread slope instability and mass-transport features suggesting several generations of failures and involving distinct mechanisms of sediment transport. Here we discuss the sedimentary processes that are believed to shape the SAM, their predisposing factors and triggers, and propose a chronology of these events. In addition, we try to ascertain if, and where, this area of high sediment instability is still prone to failure. If this is the case, the SAM may represent a potential tsunamigenic area also in the future.

\section{Setting}

\subsection{Geologic setting}

The Adriatic Sea is a foreland domain between the Southern Alps, the Apennines and the Dinarids-Hellenids foldand-thrust belts (D'Argenio and Horvath, 1984; Ricci Lucchi, 1986; Ori et al., 1986) (Fig. 1a). The mainland region adjacent to the SAM includes the emerging sectors of the Apennine foreland and provides significant structural differentiation (de Alteriis, 1995). The segmented structure of this region reflects lateral variations of the lithospheric thickness of the westward dipping Adriatic plate and gives rise to areas of more intense or more recurrent seismicity (Royden et al., 1987; Doglioni et al., 1994).

The evolution of the SAM during the Cenozoic reflects the re-activation and inversion of inherited Mesozoic extensional faults (Argnani et al., 1993). The main deformational zone, known as the south Gargano system (Colantoni et al., 1990; Tramontana et al., 1995) extends both on land, with the Monte Santangelo-Mattinata fault (Ortolani and Pagliuca, 1987), and offshore with the Gondola deformation belt (Finetti et al., 1987) (Fig. 1a). During the Quaternary, the SAM was affected by uplift and deformation (Doglioni et al., 1994). During the last $500 \mathrm{ky}$, the SAM has built through the deposition of a composite stack of regressive depositional (progradational) sequences, formed mainly through prolonged intervals of sea level fall, and bounded at the top by shelf wide erosion surfaces (Ridente and Trincardi, 2002a). Each of these sequences records a 100-120 ky-glacio-eustatic cycle (Trincardi and Correggiari 2000). Along the SAM these sequences form a composite progradational wedge with an overall forestepping architecture and a progressive seaward shift of the landward pinchout, in response to the seaward tilt of the margin (Ridente and Trincardi, 2002a). Active tectonic deformation on the continental margin generated a suite of gentle anticlines and vertical offsets that affect superficial deposits, particularly along the E-W-trending Gondola deformation belt (Fig. 2). These features indicate that tectonic deformation is occurring up to recent times (Tramontana et al., 1995; Ridente and Trincardi, 2002b), even if the interpretation of the kinematic of these tectonic features remains controversial (Colantoni et al., 1990; Argnagni et al., 1993; de Alteriis, 1995).

\subsection{Seismicity}

The SAM is a seismically active area where earthquakes are well documented both from historical catalogues over the last ten centuries and from modern registrations over the last few decades (Tinti and Armigliato, 2003). Seismic activity appears to cluster along the main tectonic structures described above, with shallow earthquakes reaching magnitudes typically between 5 and 6 on Richter scale (Tinti et al., 1995; Tinti and Armigliato, 2003). In particular, earthquakes located offshore the Gargano Promontory (Fig. 1a) reach higher energy releases with peaks greater than 6.6 on Richter 


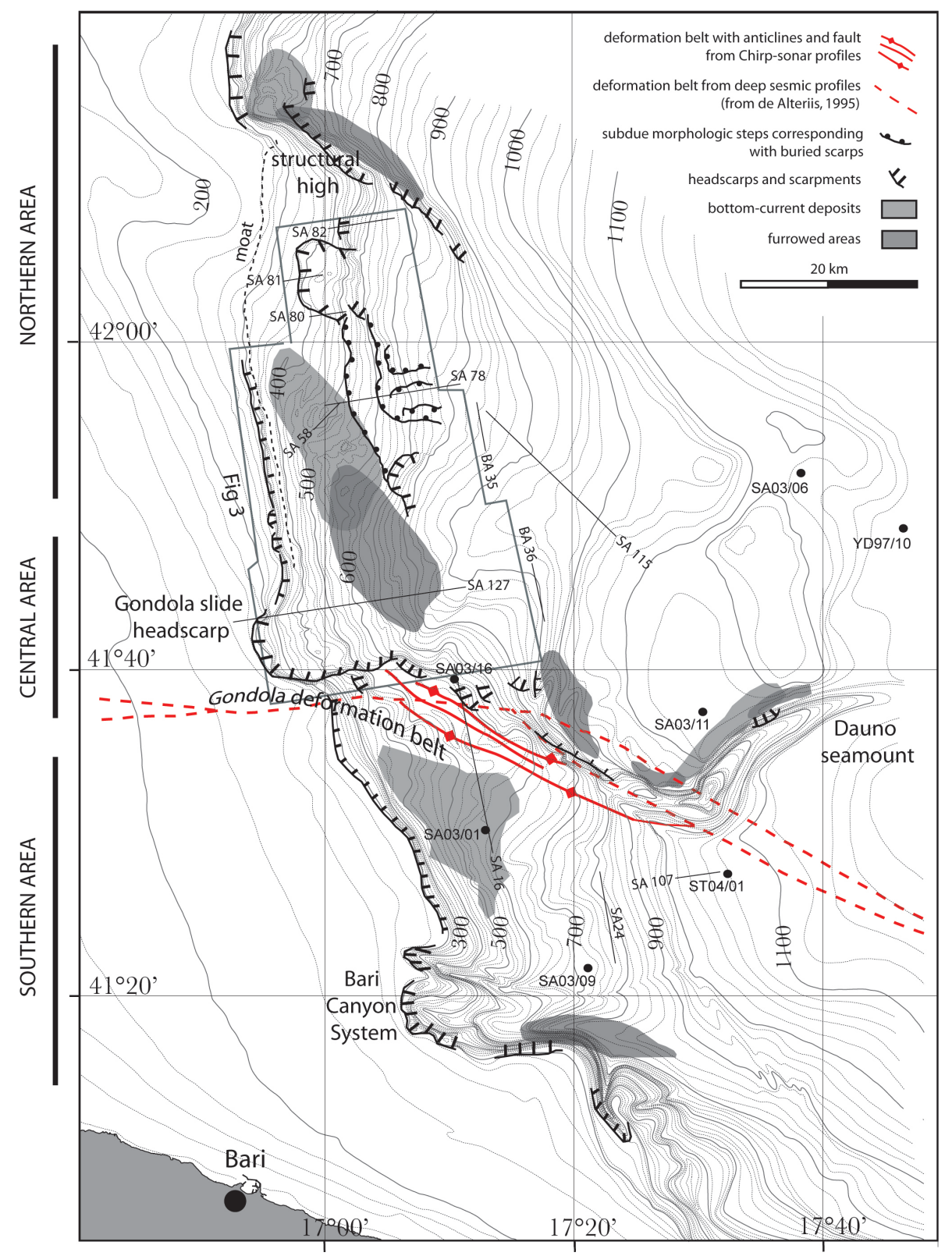

Fig. 2. Detailed bathymetry of the Southwestern Adriatic Margin (SAM) with contour intervals of $20 \mathrm{~m}$ and location of Chirp-sonar profiles and cores shown in the following figures.

scale (Tinti et al., 1995). The south Adriatic was also affected by large tsunami particularly well documented in historical times (Tinti et al., 1995), the largest of which occurred in 1627 destructing several coastal villages and killing more than 5000 people (Postpischl, 1985); this event, in particular, may have been triggered by the intense seismic activity offshore but it is difficult to explain why distructive waves hit simultaneously the coast both north and south of the Gargano Promontory, as documented by Tinti and Armigliato (2003).

\subsection{Oceanographic setting}

Two main bottom water masses impact on the SAM (Artegiani et al., 1997): the Levantine Intermediate Water (LIW) layer in a water depth of 200-700 m (Orlic et al., 1992), and the bottom layer represented by the North Adriatic Dense Water (NAdDW) (Cushman-Roisin et al., 2001). These two bottom currents flow southward along the SAM and result in current velocities exceeding $60 \mathrm{~cm} / \mathrm{s}$ along the slope (Miserocchi, personal communication). This current circulation regime may have undergone significant changes in intensity in the recent geologic past, particularly through glacial periods, when the north Adriatic shelf was subaerial and major rearrangements affected the overall Mediterranean circulation (Myers et al., 1998, Verdicchio et al., 2005). 

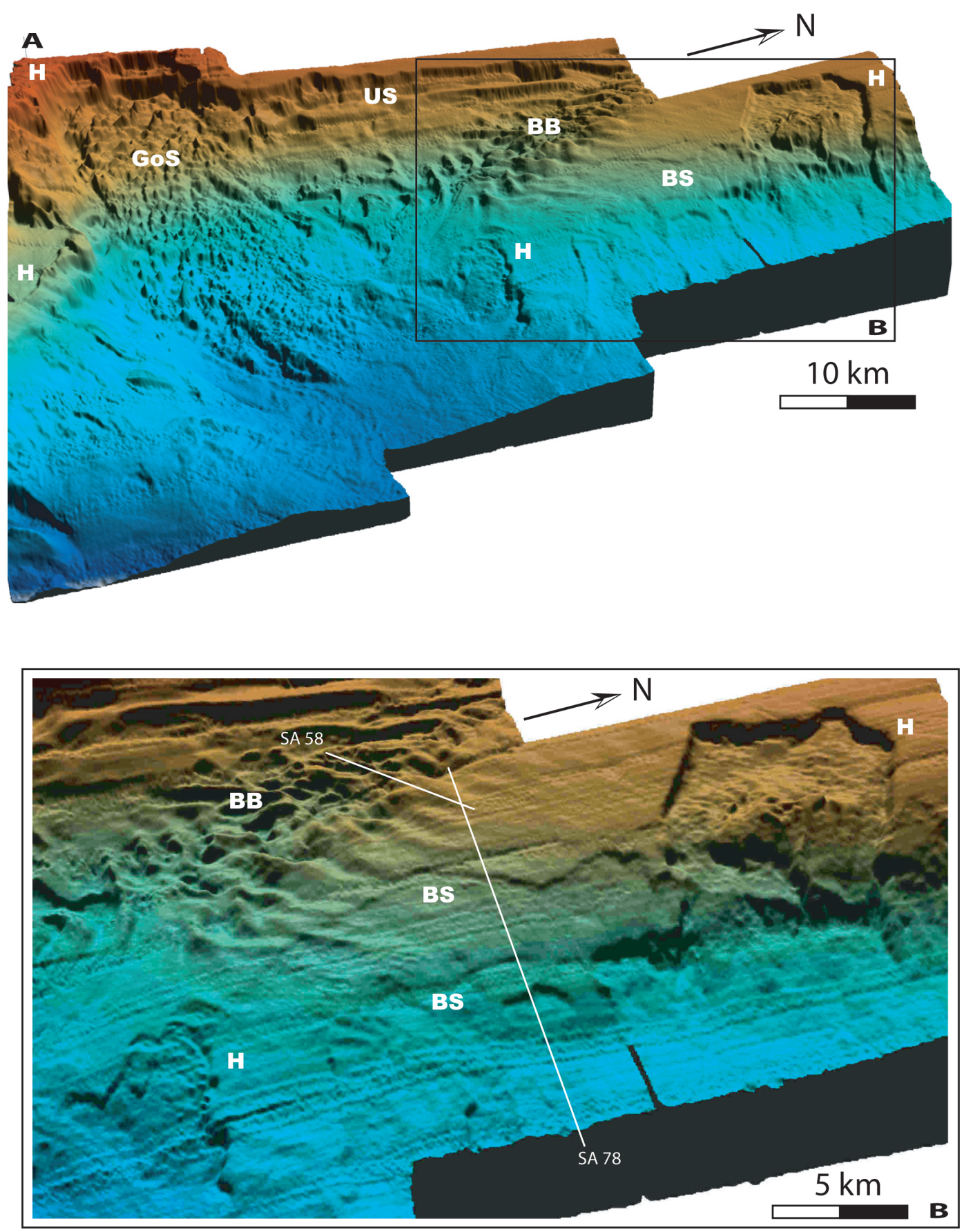

Fig. 3. (A): EM-300 multibeam bathymetry showing upper slope (US), Gondola Slide deposit (GoS), bottom-current bedforms (BB), slide headscarps (H), traces of buried scarps (BS); vertical exaggeration 5x, artificial sun angle from N, red is $150 \mathrm{~m}$, dark blue is $1000 \mathrm{~m}$. Close up (B) evidences arcuate lineations corresponding to buried scarps (BS); artificial sun angle from W; profiles SA78 and SA58 are shown in Fig. 7.

\section{Data and methods}

The data set for this study has been collected by ISMARCNR (Bologna) during three cruises on board R/V Urania (2003 and 2004) and R/V Odin Finder (2005) (Fig. 1b). The main data set includes a dense network of Chirp-sonar profiles. Chirp-sonar profiles use a $2-7 \mathrm{kHz}$ sweep-modulated band width, equivalent to a $3.5 \mathrm{kHz}$ profiler fired from 16 transducers, and have a 500-2000 ms recording length, depending on water depth. In the northern half of the study area, high-resolution bathymetric data were gathered using a 50-kHz EM-300 multibeam and reduced to a $5 \times 5 \mathrm{~m}$ grid. The remaining slope and basin area are covered by conventional bathymetric data that are anyhow sufficient to 
identify the morphologic expression of mass-transport deposits. A 30-kHz TOBI side-scan-sonar mosaic offers information about the seafloor back-scatter and macro morphology, side-scan-sonar data were processed at the "National Oceanographic Center, Southampton" following the methods defined by Le Bas et al. (1995). Sediment cores were collected using a piston corer with variable barrel lengths (5-20 m), for a maximum core recovery of circa $16 \mathrm{~m}$. In addition, a light-coring device (SW104) with a $1.35-\mathrm{m}$ barrel was employed to collect large-diameter undisturbed core tops (Magagnoli and Mengoli, 1995). Track-line positioning was based on D-GPS navigation, assuring a position accuracy of circa $10 \mathrm{~m}$, and transformed to geographic coordinates referred to the ED-50 datum.

\section{Results}

\subsection{Morphology}

\subsubsection{The upper slope}

The new bathymetric map evidences a markedly erosive upper slope dipping $1^{\circ}$ to $8^{\circ}$ and reaching a maximum of $30^{\circ}$, in the southern area (Figs. 2, 3). Where the upper slope is steeper than the bedding planes of the underlying strata, Pleistocene progradational sequences are variably exposed (Fig. 4). The relative age of the exposed sequences can be defined through seismic correlation to the shelf area (Ridente and Trincardi, 2002a).

Prominent features of the upper slope are: 1) the headscarp of Gondola Slide that has an extent of about $10 \mathrm{~km}$ along the slope, a relief up to $250 \mathrm{~m}$ and indents the shelf edge for $5 \mathrm{~km}$ truncating several stratigraphic units including, atop, a progradational sequence that postdates $120 \mathrm{ky}$ BP (Ridente and Trincardi, 2002a) (Figs. 2, 3, 4a); 2) the head of the Bari Canyon System that breaches the outer shelf over $12 \mathrm{~km}$ and presents multiple heads separated by a set of gentle anticlines whose axes intersect the shelf break and plunge eastward (Figs. 2, 5); the Bari Canyon System is EastWest and dissects the slope for about $30 \mathrm{~km} ; 3$ ) an erosional moat developing for $46 \mathrm{~km}$ at the toe of the upper slope in the northern area (Fig. 2). Additional evidence of past failures are the 10-20 m-high buried scars in the outer shelf area affecting the Pleistocene progradational sequences; these scars occur both landward of the Bari canyon head and of Gondola Slide headscarp, in both cases affecting regressive progradational sequences older than the last interglacial.

\subsubsection{The lower slope}

The lower slope of the SAM is gentler than the upper slope but, overall, shows a greater morphologic variability that likely reflects local tectonic deformation, the presence of slide headscarps, mass-transport deposits and the growth of bottom-current sediment drifts and bedforms (Verdicchio et al., 2005) (Figs. 2, 3, 7a). On the lower slope, wavystratified deposits are quite variable in thickness and ex- ternal morphology: they display short distance changes in thickness where reflectors are undulated and converge away from the depocentres, and show local seafloor or subsurface erosion; these deposits record the activity of bottom currents (Figs. 2, 7a, b). Seaward of this area, evidence of sediment instability is widespread along the slope: the seafloor is locally dissected by detachment surfaces and gentle depressions (Fig. 3), often accompanied by broad areas of exposed acoustically-transparent deposits with high backscatter (Figs. 5, 6) and/or multiple stacked acousticallytransparent deposits in the subsurface (Fig. 7b).

Major morphologic elements of the lower slope are: 1) furrowed areas particularly developed on the $\mathrm{N}$ or NE dipping flank of the main structural features intersecting the slope (Figs. 2, 5, 6a); 2) arcuate lineations extending over $20 \mathrm{~km}$ across the slope corresponding to buried scarps that define the upslope limit of buried failed deposits (Figs. 2, 3, 7b); 3) subtle depressions and offsets of otherwise undisturbed sedimentary units located landward of slide scarps, indicating short and narrow linear features and/or small pockmarks (Fig. 8); these subtle depressions appear either at the seafloor or buried, but they never extend below the reflector that correlates to the mobilization surface in the nearby failure zone; these depressions likely indicate potential landward mobilization; 4) a suite of anticlines and faults affecting shallow deposits along the Gondola deformation belt, and adjacent to slide headscarps (Fig. 7a) and well documented on side-scan sonar mosaics (Fig. 5)

\subsubsection{The basin area}

East of the SAM a 1200-m deep basin is divided in two parts by the Dauno seamount that connects with the Gondola deformation belt and reaches about $400 \mathrm{~m}$ above the adjacent basin floor (Fig. 2). Both parts of the basin are filled by buried acoustically-transparent deposits and mantled by a well stratified unit with great reflector continuity. North of Dauno seamount the basin floor displays additional local reliefs related to the presence of buried anticlines. The wellstratified uppermost seismic unit extends also across these features.

\subsection{Mass-transport features}

On the SAM, multiple and overlaying mass-transport deposits extending over $3320 \mathrm{~km}^{2}$ encompass most of the margin, between 400 and $1100 \mathrm{~m}$, and record a succession of distinct failures (Figs. 9, 10). Locally, elementary masstransport deposits overlap and coalesce so that individual deposits cannot be discerned; in this case acoustic penetration is often not sufficient to detect the base of the oldest failed unit and, consequently, the total thickness of the units involved. The mass-transport deposits are mapped individually where separated by layered stratigrafic units of variable thickness (Fig. 7b), where a high-amplitude reflector indicates stacked mass-transport units within the otherwise acoustically-transparent deposit, (Fig. 11a) and where 


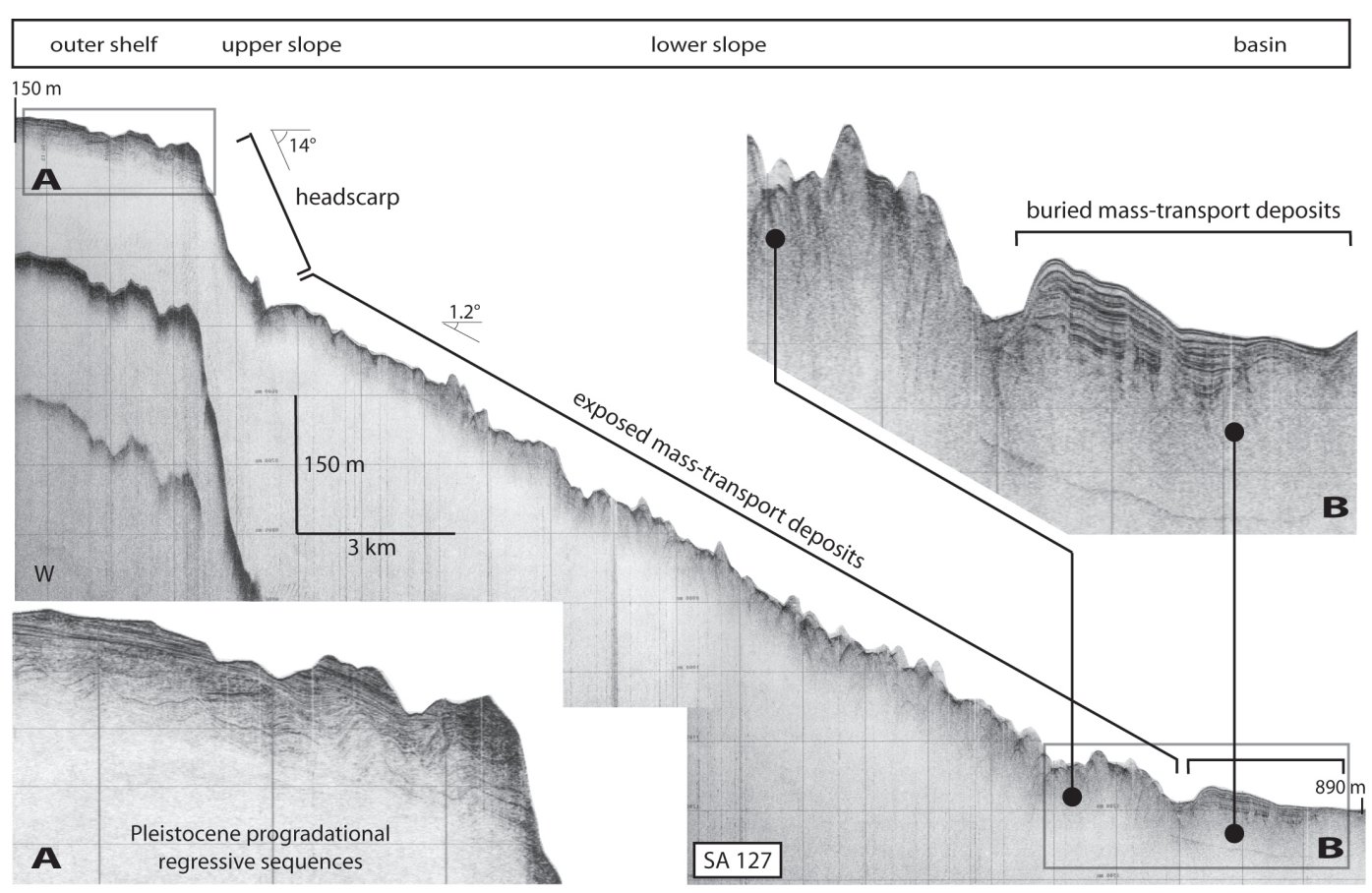

Fig. 4. Chirp-sonar profile across the Gondola Slide deposit (location in Figs. 2, 9, 10). Close-up (A) shows Pleistocene progradational regressive sequences truncated by the Gondola Slide headscarp. Close-up (B) shows the physical continuity of the exposed mass-transport deposit on the slope and the buried correlative in the basin, evidencing that bottom currents determine extensive erosion and enhanced deposition in adjacent areas.

a shallow-buried mass-transport deposit thins and allow define the underlying older failed masses (Fig. 11b); elsewhere mass-transport deposits are mapped as a whole. The uppermost buried failed deposit (indicated as GS) represents the main failure event and affects the SAM north and south of the Dauno seamount (Fig. 10).

Mass-transport deposits are either exposed at the seafloor or buried below a draped sedimentary unit. In some cases, seismic-stratigraphic correlation proves that the same mass-transport deposit can be buried in the basin area and exposed on the slope where bottom currents are active and prevent burial (Figs. 4, 7a, 11c). In other cases, several distinct failed masses superimpose displaying substantial overlaps that make it difficult to define their relative timing of deposition (Fig. 11d).

\subsubsection{Northern area}

Arcuate lineations at the seafloor, accompanied by subdue morphologic steps, extend over $20 \mathrm{~km}$ and define the upslope limit of buried failure deposits (Figs. 2, 7b, 8a). The longest and most prominent of these lineations connects the headscarps of two recent failures (Fig. 3b). These two headscarps, as many others, occur at the seafloor and are not draped by younger units, as documented on Chirp-sonar profiles (Fig. 8b). Sediment cores recovered a thin veneer of muddy bioclastic sand above some of the mass-transport deposits that are spatially associated to these headscarps. Nowhere slide scars are entirely evacuated and the basal slip surfaces are never exposed. The failed deposits have a locally-erosional base and a hummocky top, both indicative of deposition through mass-transport processes. The largest of these headscarps is $7 \mathrm{~km}$-wide and $35 \mathrm{~m}$-high (Figs. 3, 6b) and rims acoustically-transparent deposits or areas where deposits are characterized by folded and disrupted reflectors exposed at the seafloor (Fig. 8b). In a similar and adjacent failure zone, the mass-transport deposits genetically linked to the headscarp are exposed at the seafloor, proximally, and organized in several stacked units, more distally (Fig. 11d); in proximal areas, the acoustically-transparent deposits failed along a common basal layer. Because older mass-transport deposits do not extent upslope of the youngest headscarp, it is conceivable that in this area failures propagated upslope in a retrogressive style, in a fashion similar to that described by Twichell and Roberts (1982), Farre et al. (1983), and Pratson and Coakley (1996).

\subsubsection{Central area}

The central area corresponds to Gondola Slide that is part of the largest mass failure deposit (GS) on the SAM (Figs. 3, 6a). Gondola Slide is $10 \mathrm{~km}$ wide on the slope, up to $35 \mathrm{~m}$ thick and has a total run out greater than $50 \mathrm{~km}$ (Fig. 10). The evacuation zone includes a crescent-shaped headscarp located at the shelf edge with a maximum height of $250 \mathrm{~m}$ with several subparallel secondary scarps and a complex escarpment along the regional E-W structural lineation (Figs. 3, 4, 6a). On the slope, mass-transport deposits are at the seafloor 


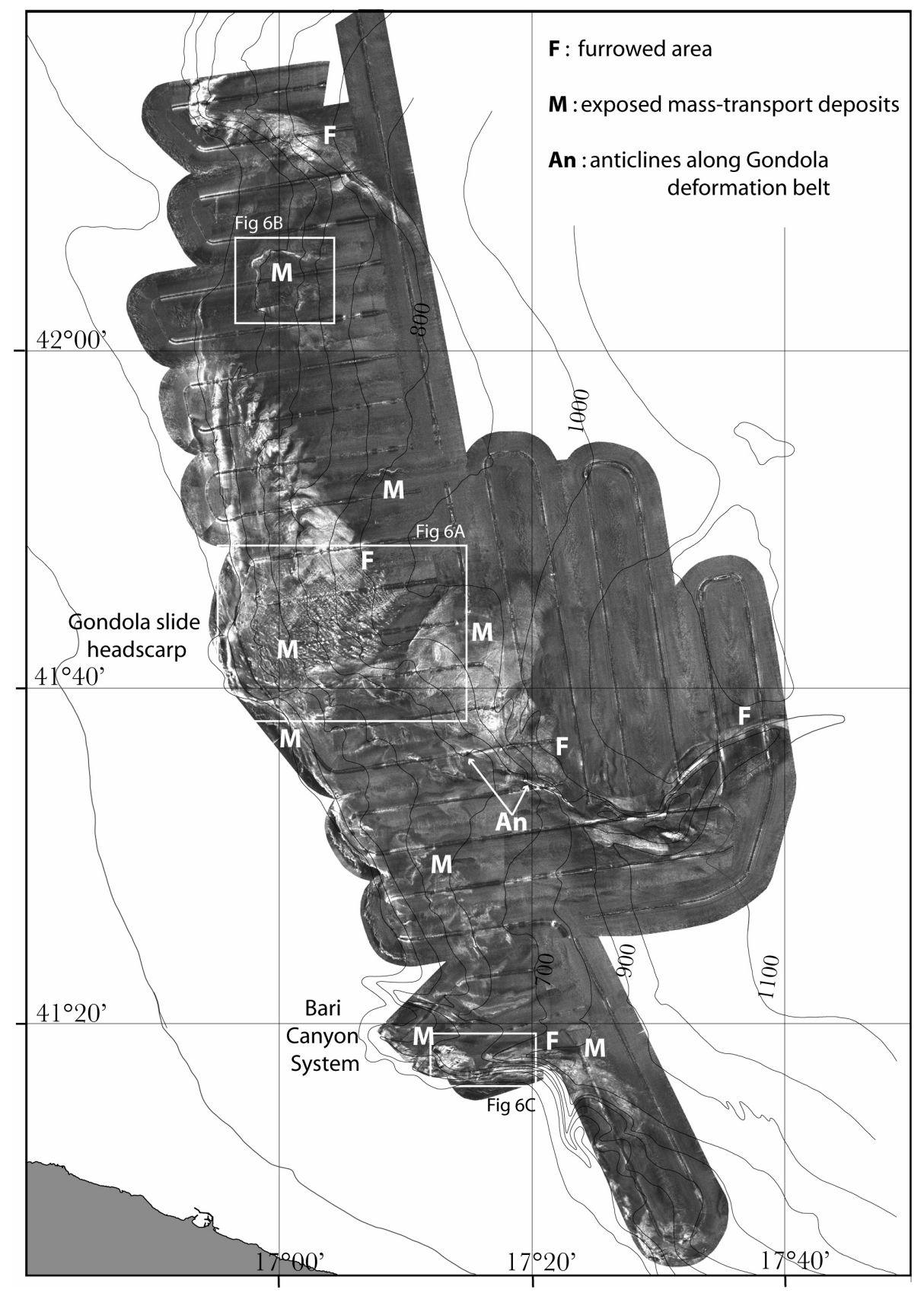

Fig. 5. TOBI side-scan-sonar image; high back-scatter (light tones) correspond to failed masses exposed at the seafloor or erosional areas, including eroded flanks of anticlines.

and correspond to a very irregular area of reduced acousticsignal penetration accompanied by diffraction hyperbolae on Chirp-sonar profiles (Fig. 4). On side-scan-sonar images, the exposed accumulation zones are characterized either by a broad area of high back-scatter with multiple low-relief steps that appear rather irregular in plane view (Fig. 5), or by highback-scatter polygonal reliefs, up to $500 \mathrm{~m}$ wide, accompanied by longitudinal stripes of alternating low and intermediate back-scatter (Fig. 6a). These stripes are interpreted as furrows (Flood, 1983) parallel to the main flow of the bottom currents (Verdicchio et al., 2005). The resulting morphologic pattern reflects the interaction between the complex relief created by down-slope gravity flows and along-slope bottom currents. On the lower slope and beneath the basin floor, acoustically-transparent deposits are generally buried under a stratified unit, locally affected by faint or disrupted reflectors (Figs. 4b, 11e). Where detectable, the base of the mass-transport deposits is erosional at the base of the slope and the top is irregular over the entire accumulation zone but with decreasing relief distally (Figs. 11c, e). A limited number of cores penetrating the slide top on the slope collected disaggregated sandy sediment encasing irregular clay chips (Fig. 7a). 

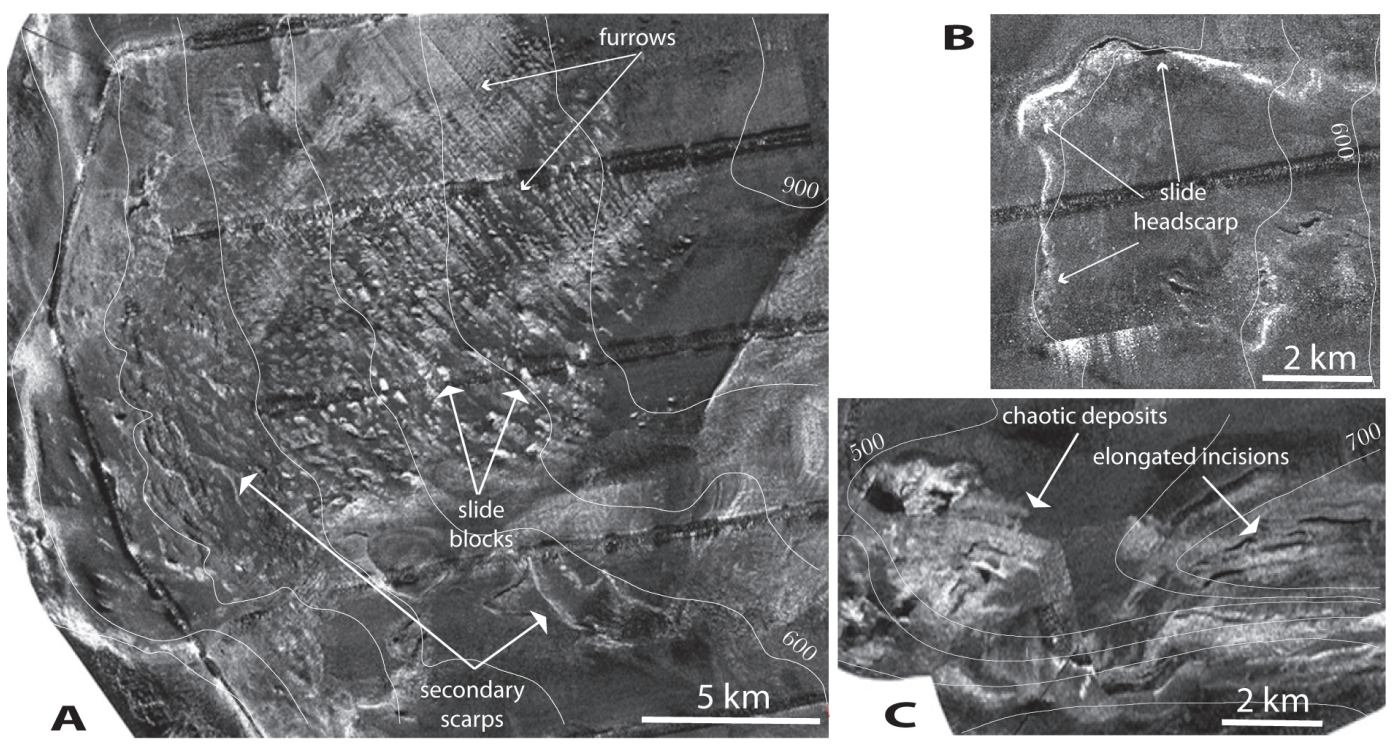

Fig. 6. Close ups of TOBI side-scan-sonar image of Fig. 5. (A): secondary scarps and blocks of the Gondola Slide, and furrows parallel to the southward flow of bottom currents; $(\mathbf{B})$ : $35 \mathrm{~m}$-high headscarp of a recent failure; $(\mathbf{C})$ : elongated incisions on the Bari canyon walls and chaotic deposit at the seafloor with high back-scatter.

\subsubsection{Southern area}

The southern area records three distinct failure events (I, II, III) predating the most extensive mass-transport deposit (GS) (Figs. 9, 10). Buried failed masses lay on irregular surfaces of pre-existing structural reliefs, are locally ponded and extend up to the erosional upper slope (Figs. 9, 11f). This $200 \mathrm{~m}$-high, 30-km long, erosional upper slope, together with the region head of the Bari Canyon System, represents the most likely source area for I, II, III mass-transport deposits (Fig. 9). At the seafloor, several 10-20 m deep incisions dissect stratified units perpendicular or slightly oblique to the regional slope defining the flanks of folds related to the Gondola deformation belt (Fig. 7a) and recording a high back-scatter signature on side-scan-sonar mosaics (Fig. 5). Erosional surfaces separate also mounded layered deposits reflecting bottom-current activity and, in some cases, mark the top of old but exposed mass-transport deposits (Fig. 7a). Recent mass wasting in the southern area occurs along the steep walls of structural highs and, particulary, along the Bari Canyon System that develops between 150 and $1100 \mathrm{~m}$ water depth. Elongated incisions on the Bari canyon walls and chaotic deposit at the seafloor with high back-scatter suggest that the canyon is impacted by mass-transport events in recent times (Figs. 5, 6c).

\subsection{Slope and basin floor stratified unit}

A plane-parallel $10-16 \mathrm{~m}$-thick stratified unit mantles the basin floor and shows great reflector continuity (Fig. 11f); approaching the base of the slope this unit thins and drapes areas of pre-existing irregular seafloor (Fig. 7b). Locally, in this area, the top of the stratified unit displays a diffused finescale roughness and the otherwise uniform reflectors are in- terrupted by a pattern of closely spaced sub-vertical disturbances with small vertical offsets, occasionally accompanied by diffraction hyperbolae, and folded reflectors (Figs. 7b, 11b). This seismic-reflector geometry is most evident where the seafloor morphology reflects the presence of shallowburied mass-transport deposits (Fig. 11e). Indeed, this unit is irregular along the slope, everywhere the underlying topography is irregular. This draped unit, however, is no longer detectable in the slope areas directly impacted by bottom currents causing sediment winnowing or erosion and in areas where more recent failure has occurred (Figs. 4, 11e). Based on the internal seismic facies and on the structure of the top surface, the acoustical anomalies of the slope and basin floor stratified unit can be ascribed to fluid escape from the thick mass-transport deposit underneath (Trincardi et al., 2004). Upslope of the buried transparent deposits the layered unit and its base correlate, respectively, to a stratigraphic unit shaped in bottom current deposits and to one of their typical internal erosional surfaces (Fig. 7b).

\subsection{Cores and stratigraphy}

Seismic-stratigraphic correlation documents that the Gondola Slide deposit is coeval with buried mass-transport deposits in the northern basin area (Figs. 10, 11e). However, the roughly E-W lineament formed by the Gondola deformation belt (Fig. 7a) and the Dauno seamount (Fig. 10) hampers seismic-stratigraphic correlation toward the south, where mass-transport deposits occupy a similar stratigraphic position (compare Figs. 7b and 11a).

Sediment cores collected north and south of the Dauno seamount document that the slope and basin floor stratified unit is essentially a clay unit with rare interbedded silt-rich clayey horizons, thin bioclastic sandy layers and 

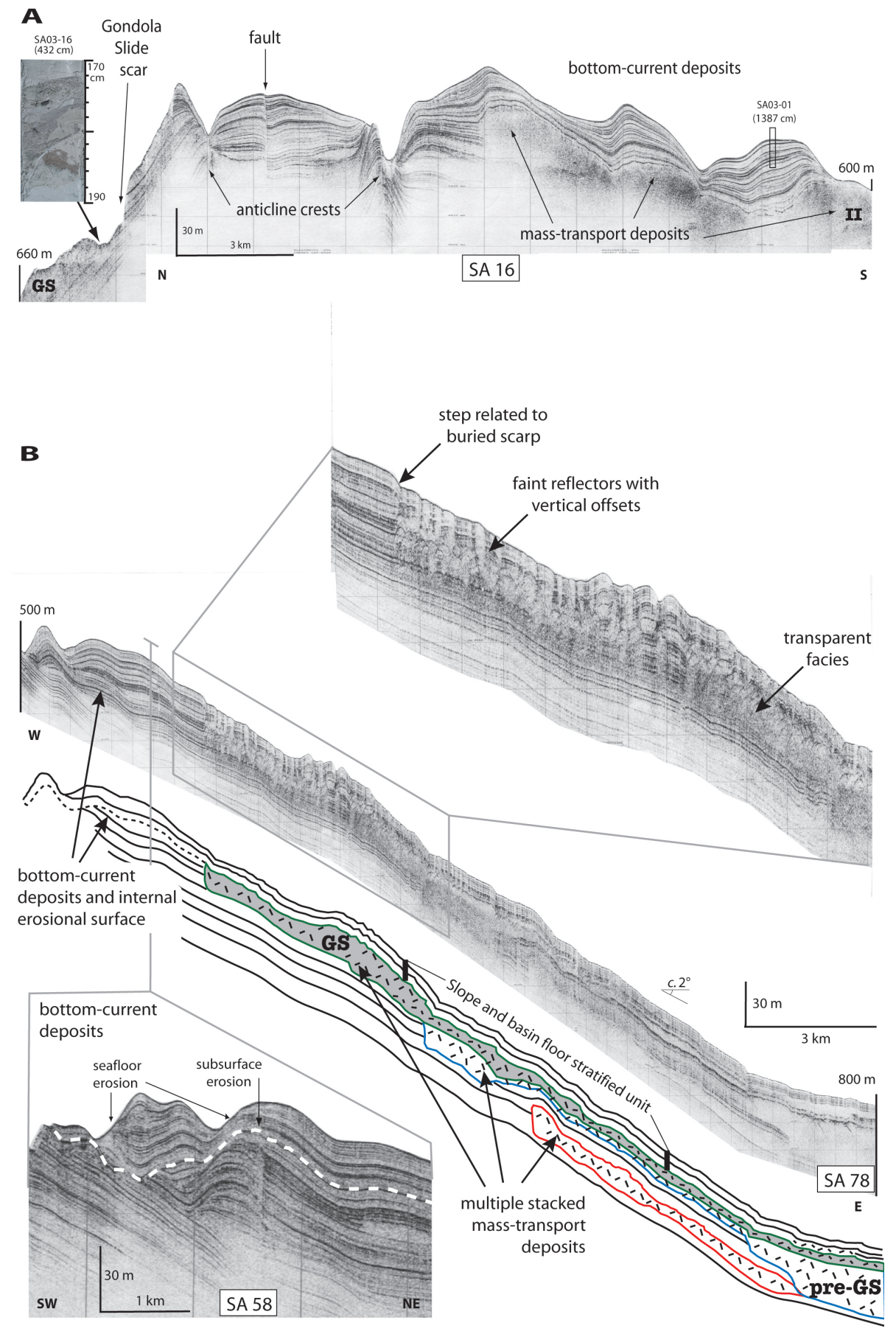

Fig. 7. (A): Chirp-sonar profile (location in Figs. 2, 9, 10) crossing the Gondola deformation belt showing a fault and two anticlines whose flanks are dissected by deep incisions; the acoustically-transparent deposits on the rigth are mass-transport deposits, partly buried by asymmetric and mounded bottom-current deposits. Core SA03-01 is discussed in Fig. 12. On the left, bedding planes steeply dip to the north providing potential slip surfaces for Gondola Slide. Core SA03-16 from Gondola Slide deposits retrieved remolded silty mud deposits. (B): Chirp-sonar profile (location in Figs. 2, 3, 9, 10) and line drawing along the lower slope showing a set of acoustic-transparent mass-transport deposits; note the layered stratigraphic units separating individual mass-transport deposits and the coalescence of mass-transport deposits basinward; a well-stratified unit mantles the seafloor with diffuse roughness and small vertical offsets (upper close-up); bottom-current bedforms (on the left) show seafloor and subbottom erosional surfaces, better imaged in a perpendicular profile (lower close-up).

volcanogenic layers either visible (and up to centimetric thicknesses) or detectable at the microscope only (Fig. 12). Core correlation is mainly based on foraminifera assem- blages (see Verdicchio et al., 2005) and magnetic susceptibility curves whose peaks commonly indicate the presence of tephra layers. Ages are ascribed to biozone boundaries 

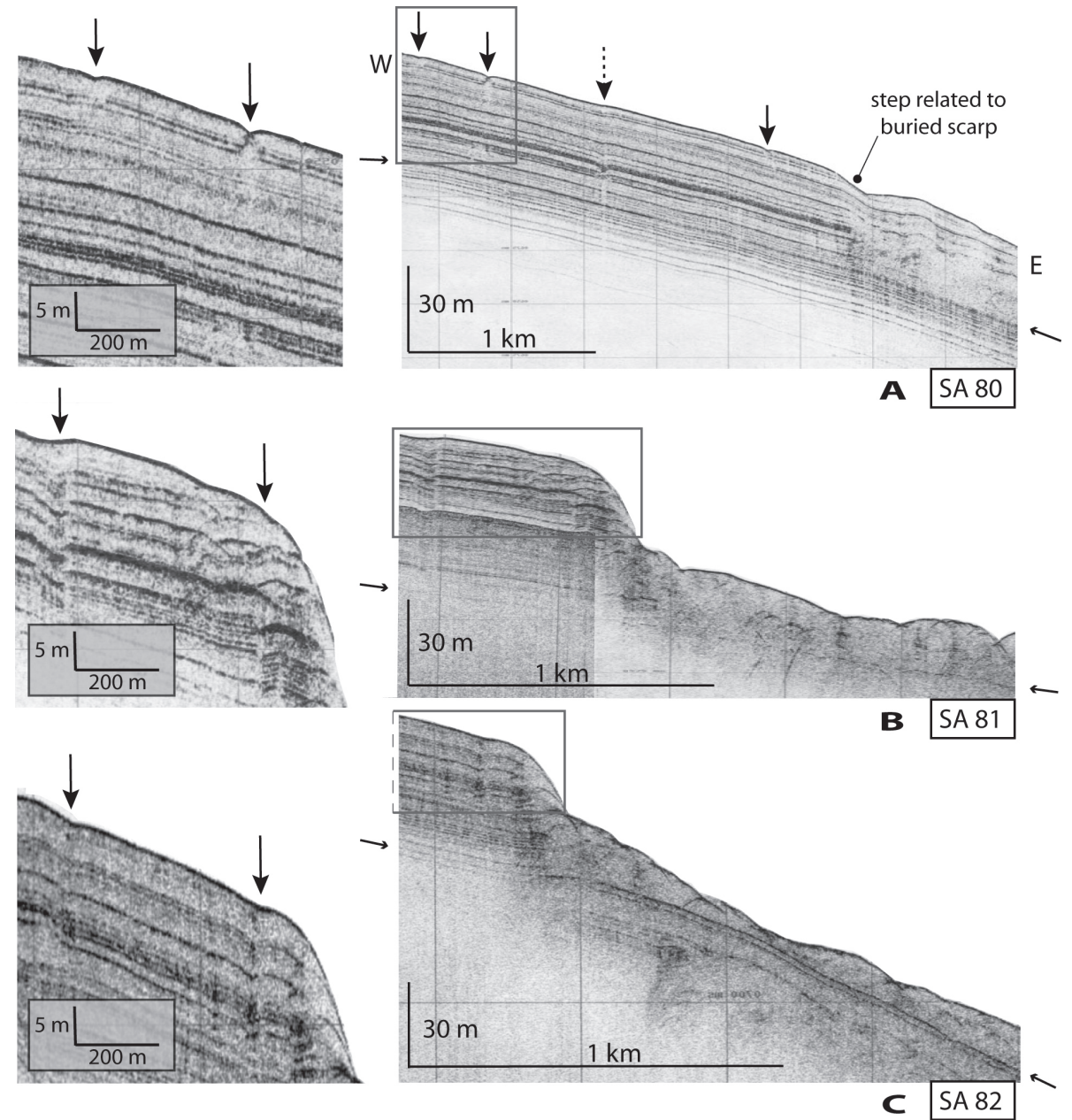

$\downarrow$ : depressions and offsets of stratified units at seafloor and
$\rightarrow \leftarrow$ : mobilization surfaces

Fig. 8. Chirp-sonar profiles (location in Figs. 2, 9, 10) and close-ups showing subtle depressions and minor reflector offsets of otherwise undisturbed sediment units at the seafloor or buried. Note that these features do not extend below the basal mobilization surfaces. Acoustically-transparent deposits lay at the base of the scarp implying that evacuation was not complete after failure.

based on published literature and framed in a well defined seismic stratigraphic context (Jorissen et al., 1993; Asioli 1996, 1999, 2001; Trincardi et al., 1996; Capotondi et al., 1999; Ariztegui et al., 2000).

The slope and basin floor stratified unit thins across the morphologic high that marks the center of the south Adriatic basin and against which Gondola Slide deposit pinches out (Figs. 10, 12). Beyond this high, piston cores YD9710 and SA03-6, into undisturbed well-stratified muddy sediment, encountered a graded fine-grained sand bed interpreted as a turbidite deposit (Fig. 12). This bed correlates, on Chirpsonar profiles, with the acoustically-transparent deposit of Gondola Slide indicating that the mass-transport produced a distal turbidite deposit beyond the failed masses mapped on the basis of Chirp-sonar profiles (Fig. 10).

Figure 12 shows two transects, north and south of the Dauno seamount, defining the age of the largest mass- transport deposit (GS), which includes Gondola Slide. Biostratigraphic information from planktonic foraminifera allow define the post-failure units above this main mass-transport deposit and its distal correlative turbidite deposits. The succession of post-failure units (both $\mathrm{N}$ and $\mathrm{S}$ of Dauno seamount) includes, from top to bottom: 1) a typically reduced thickness of late-Holocene deposits above the Last Occurrence of Globorotalia inflata (Asioli, 1996); 2) a well defined Sapropel S1 interval characterised by large specimens of Globigerinoides ruber (pink) with thin and inflated tests; all cores show evidence of a sapropel break as previously observed in the area and marked by the re-appearance of Globorotalia inflata and Globorotalia truncatulinoides (Rohling et al., 1997; Ariztegui et al., 2000); core ST0401 lacks biostratigraphic information but displays the typical change in color of the sapropel S1 and its break associated to a minimum in whole-core magnetic susceptibility; 


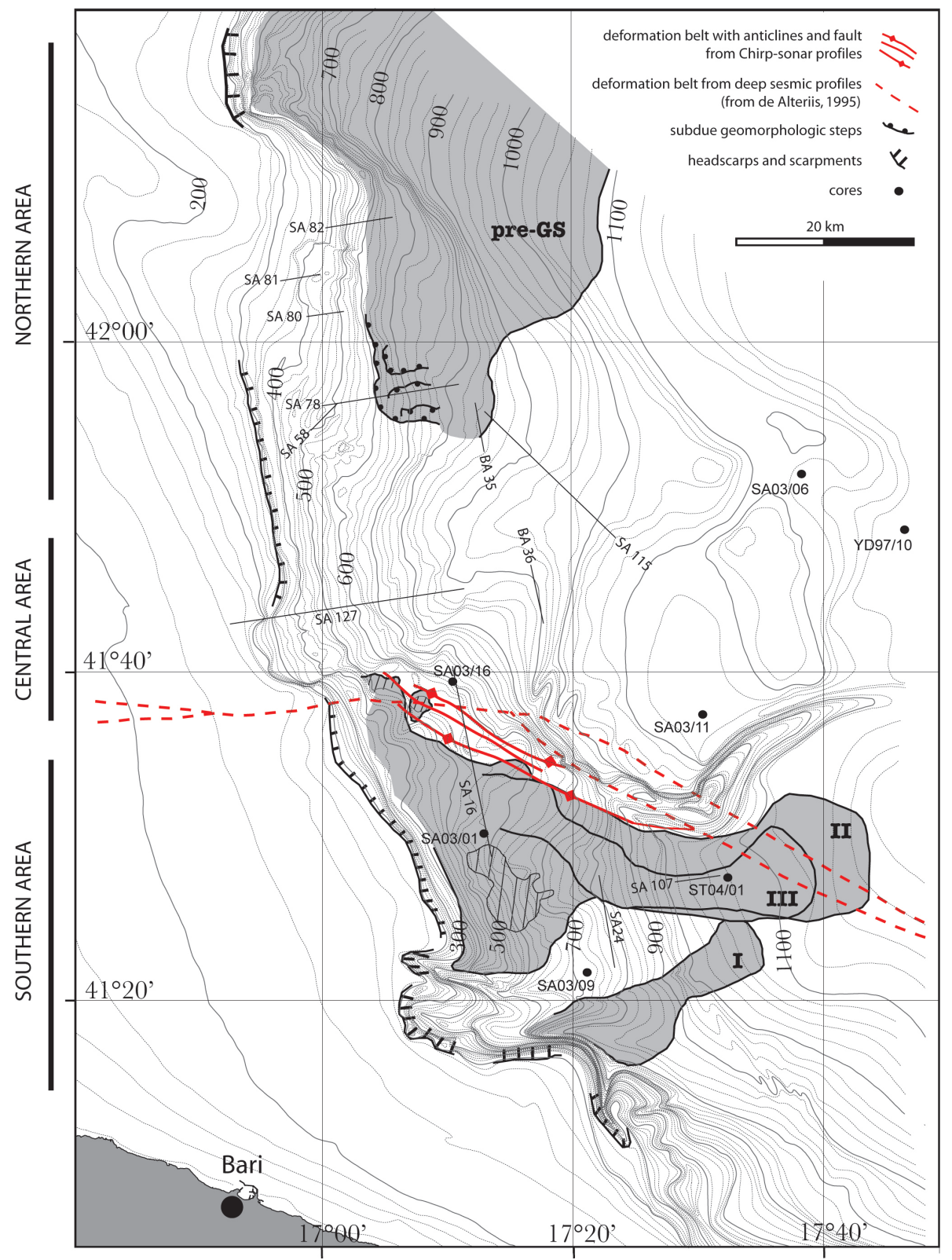

Fig. 9. Distribution of mass-transport deposits pre-dating the largest failure event of the Southwestern Adriatic Margin. Areas not delimited by solid lines correspond to uncertain boundaries. In the northern area individual failed masses coalesce and have been mapped as a whole (pre-GS). In the southern area, relative emplacement of distinct mass-transport deposits is indicated by roman numbers (dashed areas correspond to exposed failed units).

furthermore, all cores include a tephra layer into the sapropel interval corresponding to the Mercato event (Asioli et al., 1996; Calanchi et al., 1998; Siani et al., 2001; Lowe et al., 2005); 3) the pre-Boreal interval, characterised by repeated and short-term oscillations in the relative abundance of species indicative of cold and warm waters; 4) the GS-1 (Younger Dryas) interval marked by a dominant cold-water association with Globigerina bulloides, Neogloboquadrina pachyderma and Globorotalia scitula, and including a tephra layer, known as $\mathrm{C} 1$, that corresponds to the Pomici Principali event (Asioli et al., 1996; Calanchi et al., 1998;
Siani et al., 2001; Lowe et al., 2005); 5) the GI-1 interval (Bolling/Allerod) marked by a basal peak in the abundance of Globigerinoides ex gr. ruber and an oscillatory cooling trend as previously observed in the Central Adriatic (Asioli et al., 1999, 2001); 6) a glacial interval dominated by cold water species like Globigerina bulloides, Neogloboquadrina pachyderma and Globorotalia scitula (indicated as MIS 2 on Fig. 12). The top of the GS-mass-transport deposit in both sub-basins lays within this glacial unit (MIS 2).

Distal cores, in both transects, penetrated the largest slide deposit (GS) or the correlative turbidite deposits and allow 


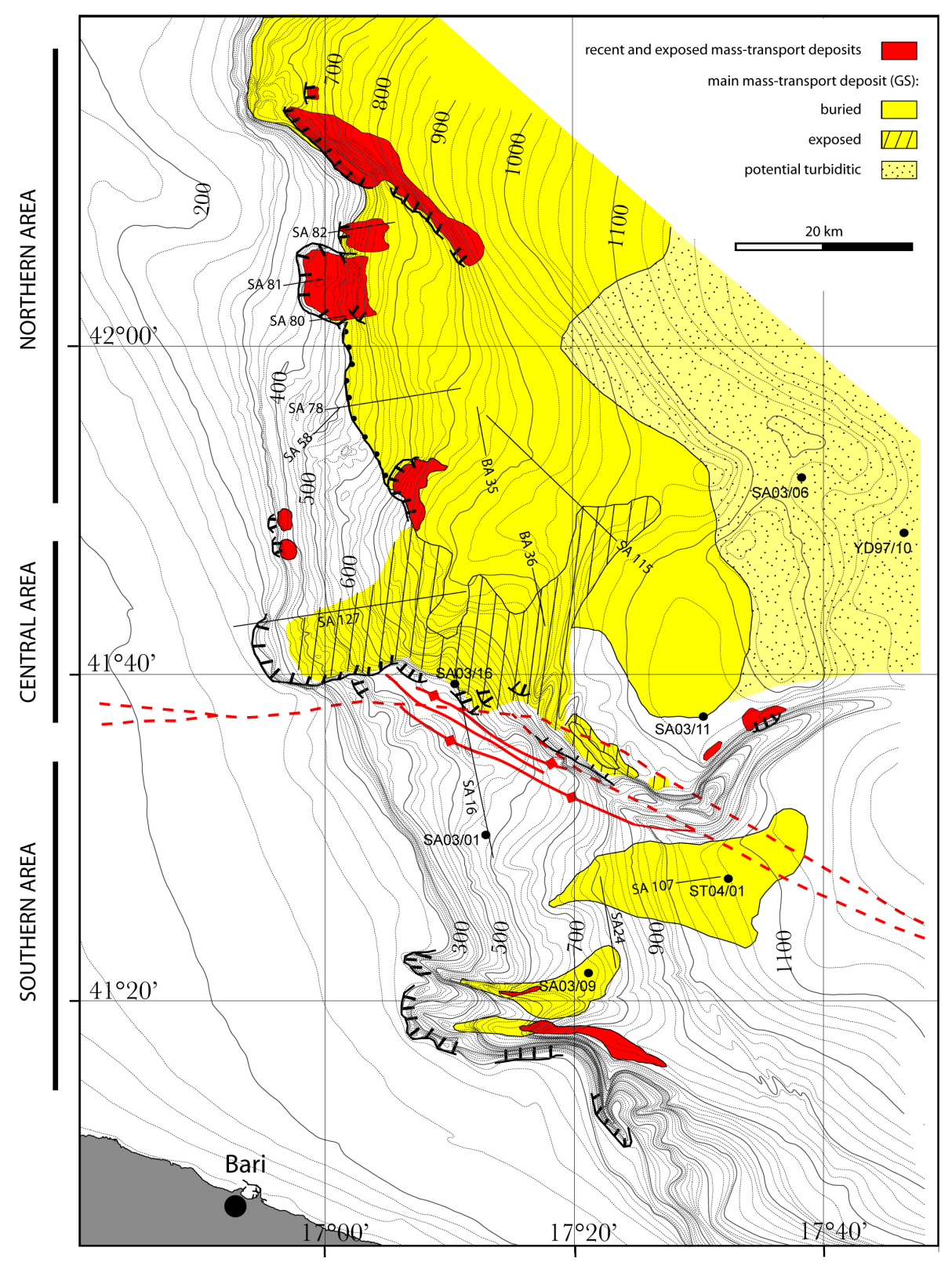

Fig. 10. Distribution of the largest mass-transport deposit (GS) in the Southwestern Adriatic Margin and of recent-most failed masses with geomorphic expression at the seafloor.

define the age of the units immediately beneath, that, in all cases, are consistent with a MIS 2 age, as confirmed also by core YD97-10 where the top of MIS 3 was reached about $3 \mathrm{~m}$ below the turbidite. In both transects the age of the mass-transport deposit, and related distal turbidites, appear comparable based on the identical succession of foraminifera associations, rapidly summarised above, and additional data including: 1) whole-core magnetic susceptibility curves; 2 ) successions of peaks in magnetic susceptibility corresponding to consistent succession of tephra layers (each occurring consistently within the same biostratigraphic association); 3 ) the presence of a two-phase tephra horizon characterised by a couplet of layers with distinctive colours (Fig. 12). The GS-mass-transport deposit and its distal correlative turbidite deposits are in the order of 20-24 ky cal. BP old, assuming a constant sediment accumulation rate within the glacial unit (MIS 2) where they occur.

In the southern area several mass-transport deposits stack on the slope and not only in the basin area. The correlation above, however, suggests that at least one event in this area is virtually coeval with the main failure event (GS) occurred northward of the Gondola deformation belt indicating a possible common trigger during the MIS 2-glacial interval (Fig. 10).

The younger age of other, overlying, mass-failure deposits is evident where headscarps and displaced masses affect the stratified units recording the post-glacial interval (Figs. 8b, c, 10). Main recent-most failures head in proximity to the 

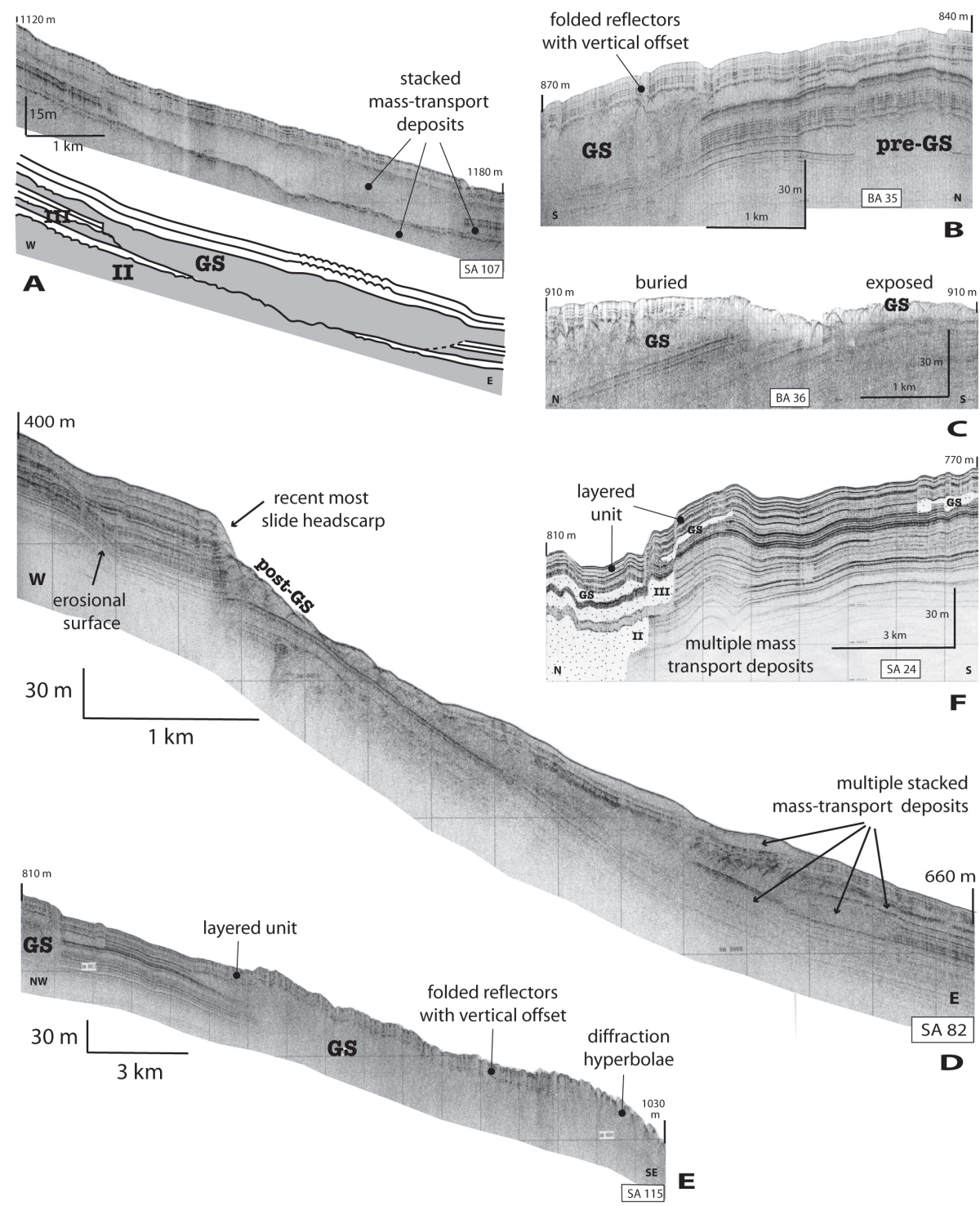

Fig. 11. Chirp sonar profiles located in Figs. 2, 9, 10. (A): coalescence of distinct mass-transport deposits (GS and III), laterally separated by stratified units; note the high-amplitude reflector with hyperbolic defractions that separate two failed masses (GS and II), otherwise undistinguishable. (B): correlation of top of a failed mass (pre-GS) and base of a younger failed mass (GS); the stratified unit that mantles the seefloor presents diffuse fine-scale roughness, sub-vertical disturbances and folded reflectors. (C): physical continuity of the same mass-transport deposit buried and exposed at the seafloor. (D): mass-transport deposits superimposed in an area of recent failure; note that mobilization surface correlates upslope with an erosional surface (arrow). (E): seismo-stratigraphic correlation between Gondola Slide deposits (right) and mass-transport deposits of the northern area (left); the uppermost stratified unit shows vertical acoustic disturbances where the failed deposit beneath is thicker; note that this draped unit is locally affected by erosion and/or failure (rigth). (F): ponded mass-transport deposits (left); uppermost failed deposits are time equivalent and correlate with the main mass-transport deposits (GS) of the Southwestern Adriatic Margin.

buried headscarps or extend further upslope affecting well stratified units. Incipient failure features distribute upslope of the recent-most slide scarps and indicate a potential generation of mass movements over a large area of the SAM, with consequent possibility of tsunamogenic hazard (Fig. 8).

\section{Discussion}

\subsection{Failed units, predisposing factors and triggers}

On the outer shelf of the SAM, Pleistocene progradational sequences, are selectively affected by repeated events of sediment failure characterized by limited displacement above downlap surfaces (Trincardi et al., 2004). On the steep upper slope these progradational sequences and the downlap 

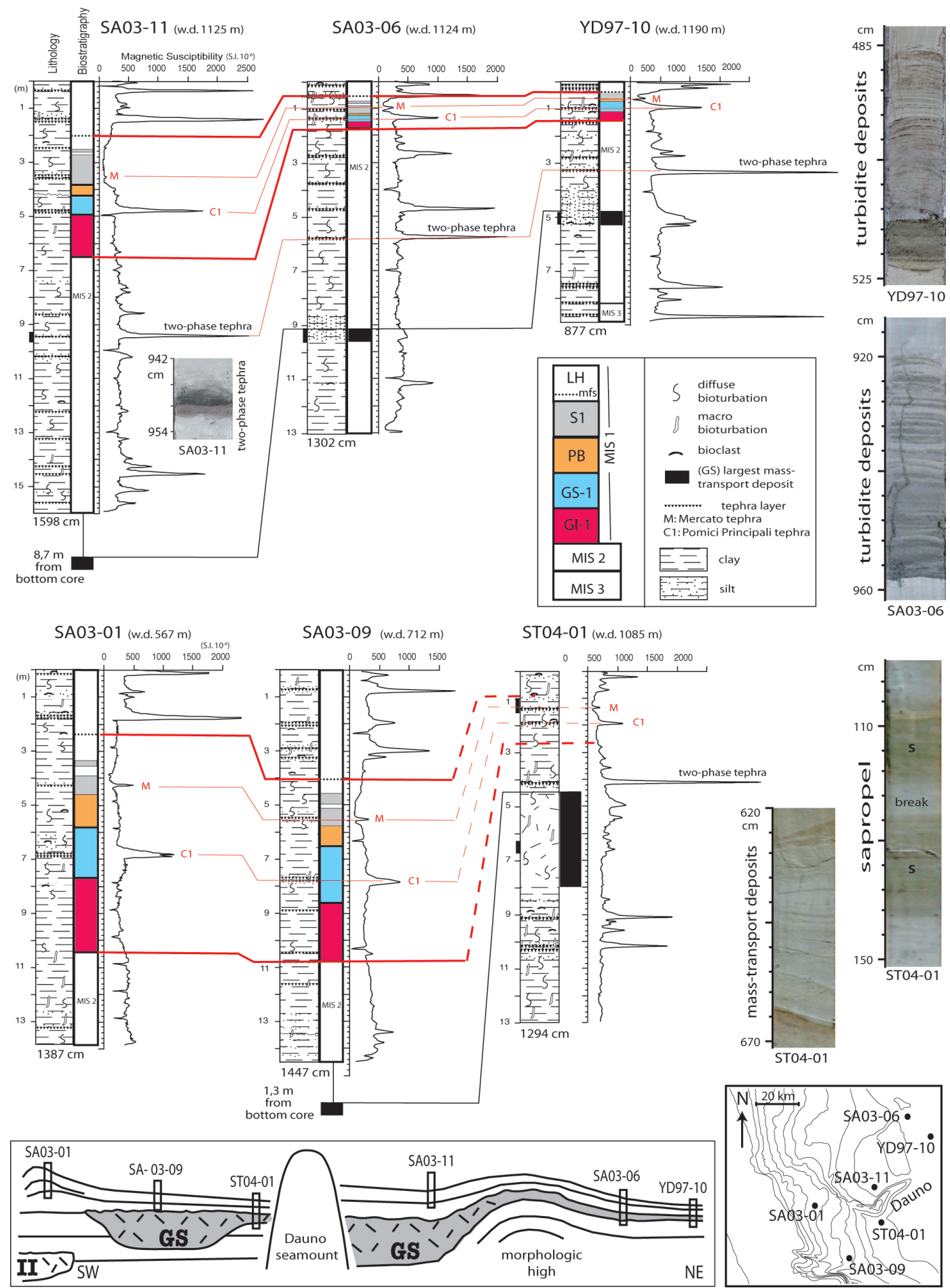

Fig. 12. Stratigraphic correlation between six piston cores, north and south of the Dauno seamount. Bold lines on the scales indicate the photographs locations. LH: late Holocene, mfs: maximum flooding surface (occurred after last sea-level rise), S1: Sapropel 1, PB: preBoreal, GS-1: Glacial Stadial 1, GI-1: Glacial Interstadial 1, MIS: Marine Isope Stage. Biostratigraphic subdivisions are based on planktonic foraminifera biozones for the Central Mediterranean region (Asioli et al., 1996, 2001; Verdicchio et al., 2005). The two core transects $\mathrm{N}$ and S of Dauno seamount reached, in the most distal cores, either the pinch out of the GS-mass-transport deposit seen on seismic profiles (southern transect, core ST04-01) or a thick turbidite deposit (northern transect) interpreted as the distal equivalent of the GS-mass-transport deposit. In both transects, the undisturbed unit above the GS-mass-transport deposit and turbidite deposits onset during the last glacial interval (MIS 2). The correlation of several stratigraphic markers (including Sapropel S1 and a two-phase tephra) suggests that failure has the same age in the whole study area. 


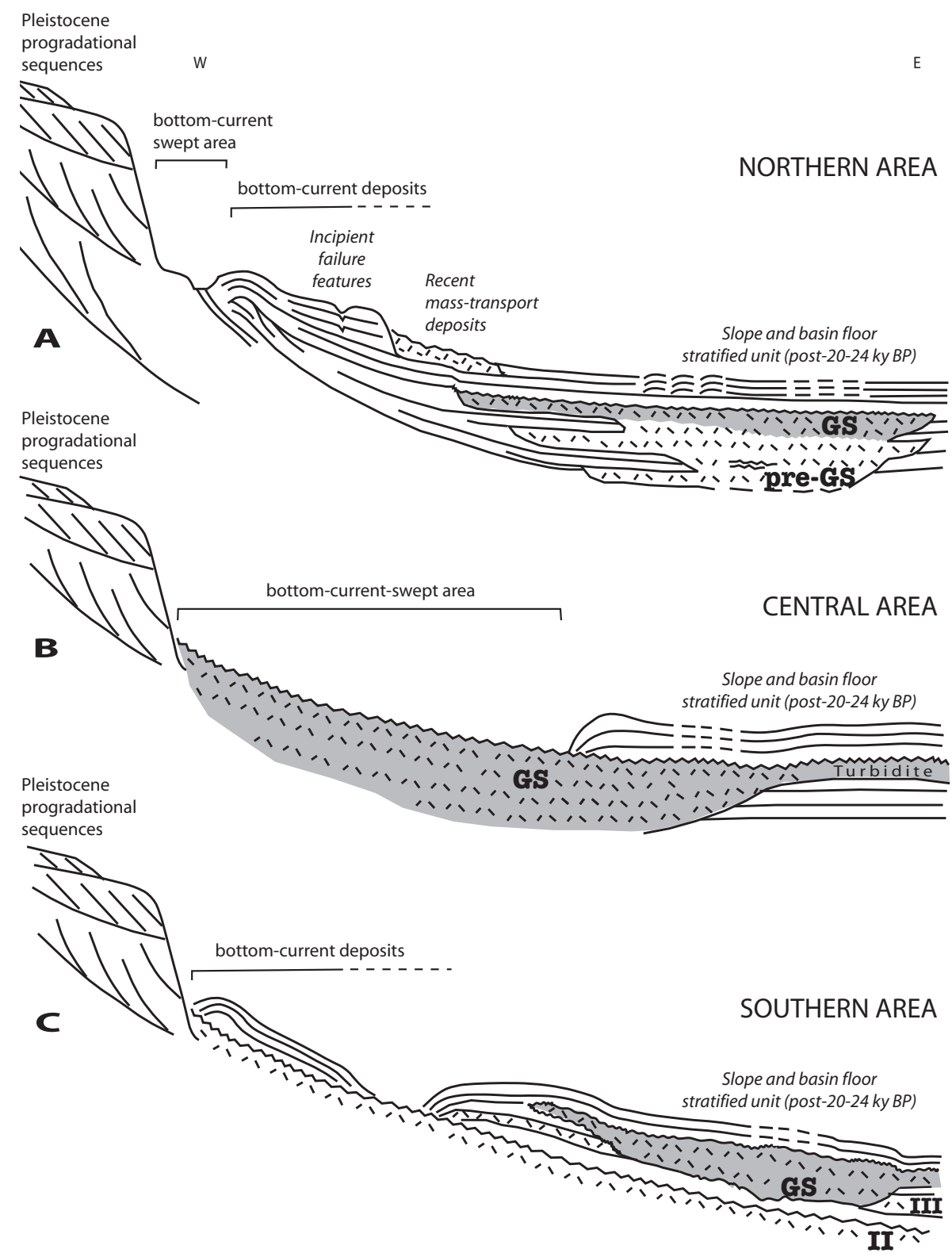

Fig. 13. Simplified stratigraphic scheme of northern, central and southern areas of the Southwestern Adriatic Margin. Note that bottom currents define areas of enhanced deposition or extensive erosion along the slope, making the age determination of the GS-event problematic.

surfaces at their base are variably truncated along the upperslope escarpment and local slide scars (Figs. 4, 13). On the lower slope, failure affects bottom-current deposits that are dominant in this area and commonly overlay older failed units; both the units affected by failure and the post-failure deposits record a similar depositional environment variably impacted by the activity of bottom currents; therefore, sediment failure did not lead to a change in depositional style in the area (Fig. 13a).

The main predisposing factors conducive to sediment instability on the SAM include: 1) active tectonism leading to local increases of margin steepness; 2) slope erosion or enhanced deposition by bottom currents; 3) occurrence of possible weak layers. Tectonic deformation affected the SAM during the last $500 \mathrm{ky}$ causing the progressive seaward tilt of the margin (Ridente and Trincardi, 2002a) while active tectonic deformation on the margin generated faults and gentle anticlines affecting shallow deposits along the E-W-trending Gondola deformation belt (Tramontana et al., 1995; Ridente and Trincardi, 2002a) (Fig. 7a). The instability of the margin was likely further enhanced through local oversteepening derived from southward erosional currents focused at the toe of the upper slope and structural highs; the incision of erosional moats may undermine the northern upper slope (Fig. 2). Sedimentation and erosion patterns are related to bottom currents whose variable activity, over the area and over time, is recorded by bottom-current deposits and multiple erosion surfaces of variable along- and down-slope extent 
both at the seafloor and deeper in the stratigraphic record (Figs. 2, 7b). Seaward of the northern bottom-current bedform field, mass-transport deposits have tops that correlate with buried erosional surfaces within the conturite deposits, thus suggesting that some failures occurred in a dominantly erosional environment where reworking of the mass transport deposit was recurrent and, later, a time-equivalent layer covered both the accumulation zone and the upslope erosional surface (Figs. 7b, 13). Other kinds of slip planes, often marked by acoustically enhanced seismic reflectors, and acting as weak layers, may coincide with buried erosional surfaces (Fig. 11d), with the irregular top of older mass-movement deposits (Fig. 11b) or with comformable layers that mark the abrupt base of the observed vertical acoustic disturbances (Fig. 8). Local tectonic deformation, erosion and sedimentation become crucial factors controlling mass movement location and size on several margins worldwide, including the northern Pacific slope where masstransport deposits appear somewhat independent from seismicity (McAdoo et al., 2000).

Recurrent seismic activity affects the SAM and likely plays a major role as a trigger for sediment instability. Earthquakes during historical times exceed 6.6 on Richter scale (Tinti et al., 1995). Earthquakes can induce large cyclic loading and remains a plausible triggering mechanism for the observed extensive mass wasting on the SAM, similarly to what has been proposed for other Adriatic areas (Correggiari et al., 2001; Cattaneo et al., 2004; Trincardi et al., 2004).

\subsection{Mass-transport styles}

The mass-transport features on the SAM slope indicate a succession of failure events involving several distinctive styles of mass movement. A similar degree of complexity has been recurrently observed in several other failure areas worldwide (e.g., Hampton et al., 1996; Mulder and Cochonat, 1996; Canals et al., 2004). On the SAM, the headscarps on the upper slope occur where the underlying progradational strata show the greatest dip seaward, a common predisposing factor also in other slide areas worldwide. In the central and southern area progradational deposits are involved in mass failure deposits, respectively exposed and buried at the base of the slope (Figs. 13b, c), while in the northern area, masses evacuated from progradational units, not imaged on Chirp-sonar profiles, are likely deeper and buried beneath the basin floor (Fig. 13a). A similar scenario is reported from other continental margins that exhibit steep and high-relief headscarps on the upper slope and buried mass wasting deposits beneath the basin floor (e.g., Twichell et al., 1993; Wilson et al., 2003).

On the slope, particularly in the northern area, masstransport deposits reflect distinct events with un-deformed layered units between failed deposits (Figs. 7b, 13a). Initially, failure occurred in response of slope over-steepening and/or of enhanced erosion driven by the intensification of southward-flowing bottom currents. After the deposition of a layered unit, a new phase of slope instability generated new failed deposits partially overlapping the previous one and locally eroding part of the underlying layered unit. These displaced deposits lack of a well-defined parent headscarp likely because in situ deformation dominated with only a minor component of downslope movement (Figs. 7b, 8a). This interpretation is supported by the evidence in the upslope part of the failed material of faint internal reflectors accompanied by small vertical offsets with little internal remolding, possibly indicating more coherent material within the deformed mass; proceeding basinward, the internal character of the failed deposit changes into a transparent facies with irregular base and top suggesting increased remolding through mass flow (Fig. 7b).

The uppermost of the buried failed deposits (GS) represents the largest failure event that affected the SAM (Fig. 10). While in the northern area this main failure event is related to in situ deformation and mass flow processes, as discussed above, in the central area the same failure is expressed by the Gondola Slide. In this area, the failure event went through significant mechanical transformations over relatively short lateral distances, undergoing changes in rheology during its downslope translation, as noted in the evolution of other failures (Hampton, 1972; Cochonat and Piper, 1995; Mulder and Cochonat, 1996; Hampton et al., 1996; Mulder et al., 1998). In fact, Gondola Slide is here interpreted as a slide transforming into mass flow and consequent further turbidite: crescentshaped $250 \mathrm{~m}$-high headscarp, secondary scarps and transverse cracks occur in the evacuation zone affected by sliding of relatively coherent masses; the high-back-scatter polygonal areas, on the slope, suggest a break up of the displaced mass into distinct slide blocks; disaggregated sandy sediment supporting irregular clay chips, recovered in the accumulation zone, indicates a further disintegration of the masstransport deposits. The significant run out distance $(>50 \mathrm{~km})$ supports the evolution of the failed mass into a flow spreading over a large area. A coarser-grained horizon within a muddy succession, cored beyond the distal pinch-out of the seismically-detectable acoustically-transparent unit, represents a distal turbiditic component of the mass-transport deposit indicating the evolution of the flow into a turbidity current.

Mass-transport style of coeval failed deposits in the southern area is complicated by the irregular pre-existing morphology that divides the GS-failed deposits in distinct ponded units and scattered depocenters (Fig. 11f).

Recent-most failed masses in the SAM are scattered along the margin, both upslope of buried mass-transport deposits and clustered along the steep walls of structural highs and the Bari Canyon System, thus representing upslope extensions or local reactivations of main failure zones (Figs. 3, 10). Some of these recent-most mass-transport deposits moved on a relatively deep weak layer, as noted along other margins (Trincardi and Field, 1992; Field, 1993; Lee at al., 2003). In some cases, these layers relate to pre-existing slip planes that locally coincide with one of the multiple detechment surfaces generated by the largest failure event. The sediment mobilization was thus likely confined to a thin horizon, leading 
to the collapse of the sediment above it; folding of beds was possibly brought about by the interaction between downslope transport and shear resistance on the overlying sediment pile (Fig. 8b).

\subsection{Timing of failure}

Although the evidence of sediment failure is widespread on the SAM slope, dating individual mass-failure events is complicated by the following main factors: 1) the excessive depth of burial of the oldest mass-transport deposits (I, II, III) that prevents sampling by conventional coring; 2) the stacking of multiple mass-transport deposits that prevents precise correlation of some of the oldest units (pre-GS); 3) the lack of post-failure sedimentary units not only in the youngest deposits but also in some areas where bottom currents sweep the seafloor leaving the slide age undetermined (GS). In addition, and more in general, we still lack a sufficient number of sediment cores to allow dating of each individual mass failures on the SAM. However, despite these limitations some basic information on the timing of sediment failure on the SAM comes from seismic-stratigraphic architecture, sea floor morphology, and sediment cores correlation (Fig. 12).

The largest failure event (GS) occurred within the MIS 2-glacial unit (in the order of 20-24 ky cal. BP) as most sequence-stratigraphy models predict during low sea-level intervals (e.g., Posamentier et al., 1988). During low sealevel intervals failed deposits are widely recognized in the deepest areas of the Mediterranean Sea (e.g., Rothwell et al., 1998; Reader et al., 2000; Trincardi et al., 2004).

Interestingly, growing evidence from the study area and other sub-basins in the Mediterranean Sea indicate that failures occurs also during overall sea-level rise conditions (e.g., Trincardi et al., 2003; Canals et al., 2004, and references therein). On the SAM, these more recent failure events result in several mass-transport deposits of small size. Nevertheless, these deposits confirm the unstable nature of the margin.

\subsection{Incipient failures and tsunamogenic area}

The occurrence of a new large-scale slope failure on the SAM is possible, as the area shows clear-cut scarps that delimit sediment units and disappear on key seaward-dipping reflectors interpreted as possible weak layers. These scarps occur upslope of older mass-transport deposits that are either buried or exposed at the seafloor (Fig. 8). In some cases, subdued morphologic steps are also associated to buried masstransport deposits (Figs. 3b, 7b), an erosional moat undermining the upper slope (Fig. 2) and subtle depressions accompanied by modest offsets of the underlying seismic reflectors indicating short and narrow linear features and/or small pockmarks (Fig. 8). This evidence characterizes an area of tens of kilometers along the slope. All together these features define areas that are still prone to failure that may occur as part of a longer-term retrogressive trend.
It is also possible that some of the largest failure deposits generated tsunami in the past. In the case of Gondola Slide, this hypothesis is supported by 1) the significant height of the head scarp (as much as $250 \mathrm{~m}$ ), 2) the initial sliding that presumebly mobilized coherent masses as supported by the presence of relatively large blocks in the proximal area, and 3) the slide scar breaching the shelf break and therefore indicating failure in shallow water, particularly if taking place during the last glacial interval (MIS2) when sea level was $120 \mathrm{~m}$ lower than today (Fairbanks, 1989). Together these characters are key in the generation of a tsunami.

\section{Conclusions}

Multiple slide scars and extensive, buried or exposed, masstransport deposits testify widespread and recurrent sediment failure events on the Southwestern Adriatic Margin (SAM). A preliminary overview of the margin morphology and stratigraphy supports the following conclusions:

1. Distinctive failure styles range from in situ sediment deformation to sliding and mass transport with run out distances up to more than $50 \mathrm{~km}$ and evolving, distally, in turbidity currents.

2. The most widespread failure event affected the SAM during the MIS 2-glacial interval, north and south of the Dauno seamount on a combined area of $2670 \mathrm{~km}^{2}$.

3. After the main phase of failure, the lower slope and basin floor was progressively buried by a thick and layered unit; the slope shallower than about $700 \mathrm{~m}$, instead, remained exposed to the waxing of bottom currents that prevented deposition or focused sediment to confined areas (Fig. 13). Locally, the resulting bottom-current deposits were affected by additional failure in recent times.

4. The most recent failure areas are several, but appear smaller in extent, and more limited in displacement compared with older events. These most recent failures typically occur on pre-existing seaward dipping slip planes and represent local reactivations or an upslope (retrogressive) propagation of slope failure after the MIS 2-glacial interval.

5. The margin shows elongated steps and clear-cut scarps indicating possible incipient failure further upslope of the areas that failed most recently. This evidence, together with evidence of seismic activity and tectonic deformation, indicates that a large area of the SAM may still be prone to failure. Further studies should define the extent of these failures and their potential in tsunami generation.

Acknowledgements. This study was supported by the European project EUROSTRATAFORM (EC contract no. EVK3-CT-200200079). We thank the captains and crews of $\mathrm{R} / \mathrm{V}$ Urania, $\mathrm{R} / \mathrm{V}$ Odin Finder, the TOBI team and all participants to campaigns 
SAGA-03, STRATA-04 and BARI-05. This is ISMAR-Bologna (CNR) contribution no. 1472.

Edited by: S. Tinti

Reviewed by: H. Haflidason and another referee

\section{References}

Argnani, A., Favali, P., Frugoni, F., Gasperini, M., Ligi, M., Marani, M., Mattietti, G., and Mele, G.: Foreland deformational pattern in the southern Adriatic sea, Annali di Geofisica, 36, 229-247, 1993.

Ariztegui, D., Asioli, A., Lowe, J. J., Trincardi, F., Vigliotti, L., Tamburini, F., Chondrogianni, C., Accorsi, C. A., Bandini Mazzanti, M., Mercuri, A. M., van der Kaars, S., McKenzie, J. A., and Oldfield, F.: Palaeoclimate and the formation of sapropel S1; inferences from late Quaternary lacustrine and marine sequences in the central Mediterranean region, Palaeogeography, Palaeoclimatology, Palaeoecology, 158, 215-240, 2000.

Artegiani, A., Bregant, D., Paschini, E., Pinardi, N., Raicich, F., and Russo, A.: The Adriatic Sea general circulation. Part II: Baroclinic circulation structure, J. Phys. Oceanography, 27, 15151532, 1997.

Asioli, A.: High resolution foraminifera biostratigraphy in the central Adriatic basin during the last deglaciation: a contribution to the PALICLAS project, Memorie Istituto Italiano Idrobiologia, 55, 197-217, 1996.

Asioli, A., Trincardi, F., Lowe, J. J., and Oldfield, F.: Shortterm climate changes during the Last Glacial-Holocene transition: comparison between Mediterranean records and the GRIP event stratigraphy, J. Quaternary Sci., 14, 373-381, 1999.

Asioli, A., Trincardi, F., Lowe, J. J., Ariztegui, D., Langone, L., and Oldfield, F.: Sub-millennial climatic oscillations in the Central Adriatic during the last deglaciation: paleoceanographic implications, Quaternary Science Reviews, 20, 33-53, 2001

Calanchi, N., Cattaneo, A., Dinelli, E., Gasparotto, G., and Lucchini, F.: Tephra layer in Late Quaternary sediments of the Central Adriatic Sea, Mar. Geology, 149, 191-209, 1998.

Canals, M., Lastras, G., Urgeles, J. L., et al.: Slope failure dynamics and impacts from seafloor and shallow sub-seafloor geophysical data:case studies from the COSTA project, Mar. Geo., 213, 9-72, 2004.

Capotondi, L., Borsetti, A. M., and Morigi C.: Foraminiferal ecozone, a high resolution proxy for the late Quaternari biochronology in the central Mediterranean Sea, Mar. Geology, 153, 253$274,1999$.

Cattaneo, A., Correggiari, A., Marsset, T., Thomas, Y., Marsset, B., and Trincardi, F.: Seafloor undulation pattern on the Adriatic shelf and comparison to deep-water sediment waves, Mar. Geo., 213, 121-148, 2004

Cochonat, P. and Piper, D. J. W.: Source area of sediments contributing to the "Grand Banks" 1929 turbidity current, in: Atlas of deep water environments; architectural style in turbidite systems, edited by: Pickering, K. T., Hiscott, R. N., Kenyon, N. H., Ricci Lucchi, F., and Smith, R. D. A., Chapman and Hall, London, U.K., 12-13, 1995.

Colantoni, P., Preti, M., and Villani, B.: Sistema deposizionale e linea di riva olocenica sommersi in Adriatico e al largo di Ravenna, Giornale di Geologia, 52, 1-18, 1990.

Correggiari, A., Trincardi, F., Langone, L., and Roveri, M.: Styles of failure in heavily-sedimented highstand prodelta wedges on the Adriatic shelf, J. Sedimentary Res., 71, 218-236, 2001.

Cushman-Roisin, B., Gacic, M., Poulain, P. M., and Artegiani, A.: Physical oceanography of the Adriatic Sea - past, present and future, Kluver Acad. Publ., Dordrecht, The Netherlands, pp. 304, 2001.

D'Argenio, B. and Horvarth, F.: Some remarks on teh deformation history of Adria, from the Mesozoic to the Tertiary, Ann. Geophys., 2, 143-146, 1984.

de Alteriis, G.: Different foreland basins in Italy: examples from the Central and Southern Adriatic Sea, Tectonophysics, 252, 349373, 1995.

Doglioni, C., Mongelli, F., and Pieri, P.: The Puglia uplift (SE Italy): an anomaly in the foreland of the Apennine subduction due to buckling of a thick continental lithosphere, Tectonics, 13, 1309-1321, 1994.

Fairbanks, R. G.: A 17000 year glacio-eustatic sea level record: influence of glacial melting rates on the Younger Dryas event and deep-ocean circulation, Nature, 342, 637-642, 1989.

Farre, J. A., McGregor, B. A., Ryan, W. B. F., and Robb, J. M.: Breaching the shelf; Passage from youthful to mature phase in submarine canyon evolution, in: The shelfbreak: Critical interface on continental margins, edited by: Stanley, D. J. and Moore, G. T., Society of Economic Paleontologists and Mineralogists, Spec. Publ., 33, 25-39, 1983.

Field, M. E.: Liquefaction of continental shelf sediment; the Northern California earthquake of 1980, in: Submarine landslides; selected studies in the U.S. Exclusive Economic Zone, edited by: Schwab, W. C., Lee, H. J., and Twichell, D. C., USGS Bull., 2002, 60-68, 1993.

Finetti, I., Bricchi, G., Del Ben, A., Pipan, A., and Xuan, Z.: Geophysical study of the Adria plate, Mem. Soc. Geol. It., 40, 335344, 1987.

Fryer, G. J., Watts, P., and Pratson L. F.: Source of the great tsunami of 1 April 1946: a landslide in the upper Aleutian forearc, Mar. Geol., 203, 201-218, 2004.

Gardner, J. V., Van den Ameele, E. J., Gelfenbaum, G., Barnhardt, W., Lee, H. J., and Palmer, S.: Mapping southern Puget Sound delta fronts after 2001 earthquake, Eos, Transactions, American Geophysical Union, 82, 485, 488-489, 2001.

Geist, E. L.: Origin of the 17 July 1998 Pappau New Guinea tsunami: earthquake or landslide?, Seismological Res. Lett., 71, 344-355, 2000.

Hampton, M. A.: The role of subaqueous debris flow in generating turbidity currents, J. Sediment. Petrol., 42, 775-793, 1972.

Hampton, M. A, Lee, H. J, and Locat, J.: Submarine landslides, Rev. Geophys., 34, 1, 33-59, 1996.

Hasegawa, H. S. and Kanamori, H.: Source mechanism of the magnitude 7.2 Grand Banks earthquake of November 18, 1929 : double-couple or submarine landslide?, Bull. Seism. Soc.Am., 77, 1984-2004, 1987.

Jorissen, F. J., Asioli, A., Borsetti, A. M., Capotondi, L., de Visser, J. P., Hilgen, F. J., Rohling, E. J., van der Borg, K., VergnaudGrazzini, C., and Zachariasse, W. J.: Late Quaternary central Mediterranean biochronology, Mar. Micropalaeontology, 21, 169-189, 1993.

Julian, B. R., Miller, A. D., and Foulger, G. R.: Non-double couple earthquakes, 1 Theory, Rev. Geophys., 36, 525-550, 1998.

Le Bas, T. P., Mason, D. C., and Millard, N. W.: TOBI Image Processing - The State of the Art, IEEE J. Oceanic Engineering, 20 , 85-93, 1995.

Lee, H. J., Kayen, R. E., Gardner, J. V., and Locat, J.: Characteristic of several tsunamogenic submarine landslides, in: Submarine 
Mass Movements and their Consequences, edited by: Locat, J. and Mienert, J., Kluver Acad. Publ., Dordrecht, The Netherlands, 357-366, 2003

Lowe, J. J., Blockley, S., Trincardi, F., Asioli, A., Cattaneo, A., Matthews, I. P., Pollard, M., and Wulf, S.: Age modelling of late Quaternary marine sequences in the Adriatic: towards improved precision and accuracy using volcanic event stratigraphy, Continental Shelf Research, accepted, 2005.

Magagnoli, A. and Mengoli, M.: Carotiere a gravità SW-104, Rapporto Tecnico CNR, 27, pp. 45, 1995.

Malinverno, A., Ryan, W. B. F., Auffret, G. A., and Pautot, G.: Sonar images of the path of recent failure events on the continental margin off Nice, France, Special Paper - Geological Soc. Amer., 229, 59-75, 1988.

McAdoo, B. G., Pratson, L. F., and Orange, D. L.: Submarine landslide morphology, US continental slope, Mar. Geo., 169, 103 136, 2000.

Mulder, T. and Cochonat, P.: Classification of offshore mass movements, J. Sedimentary Res., 66, 1, 43-57, 1996.

Mulder, T., Savoye, B., Piper, D. J. W., and Syvitski, J. P. M.: The Var submarine sedimentary system; understanding Holocene sediment delivery processes and their importance to the geological record, Geological Soc. Special Publications, 129, 145-166, 1998.

Myers, P. G., Haines, K., and Rohling, E. J.: Modeling the paleocirculation of the Mediterranean: the last glacial maximum and the Holocene with emphasis on the formation of Sapropel S1, Paleoceanography, 13(6), 586-606, 1998.

Ori, G. G., Roveri M., and Vannoni, F.: Plio-Pleistocene sedimentation in the Apenninic-Adriatic foredeep (Central Adriatic sea, Italy), in: Foreland Basins, edited by: Allen, P. A. and Homewood, P., IAS Spec. Publ., 8, 183-198, 1986.

Orlic, M., Gicic, M., and La Violette, P. E.: The currents and circulation of the Adriatic Sea, Oceanologica Acta, 15, 109-122, 1992.

Ortolani, F. and Pagliuca, S.: Tettonica transpressiva nel Gargano e rapporti con le catene Appenninica e Dinarica, Mem. Soc. Geol. It., 38, 205-224, 1987.

Posamentier, H. W. and Vail, P. R.: Eustatic control on clastic deposition, II-sequence and systems trast models, in: Sea-Level Changes - An integrated Approach, edited by: Wilgus, C. K., Hastings, B. S., Kendall, C. G. S. C., et al., Soc. Economic Paleontologists and Mineralogists, Spec. Publ., 42, 125-154, 1988.

Postpischl, D.: Atlas of isoseismal maps of Italian earthquakes, Quaderni de "La ricerca scientifica", 114-2A, CNR, Roma, pp. 164, 1985.

Pratson, L. F. and Coakley, B. J.: A model for the headward erosion of submarine canyons induced by downslope-eroding sediment flows, GSA Bull., 108, 2, 225-234, 1996.

Reeder, M. S., Rothwell, R. G., and Stow, D. A. V.: Influence of sea level and basin physiography on emplacement of the late Pleistocene Herodotus Basin Megaturbidite, SE Mediterraenan Sea, Mar. Petr. Geo., 17, 199-218, 2000.

Ricci Lucchi, F.: The Oligocene to recent foreland basins of the Northern Apennines, in: Foreland Basins, Allen, P. A. and Homewood, P., IAS Spec. Publ., 8, 105-139, 1986.

Ridente, D. and Trincardi, F.: Eustatic and tectonic control on deposition and lateral variability of Quaternary regressive sequences in the Adriatic basin, Mar. Geology, 184, 273-293, 2002a.

Ridente, D. and Trincardi, F.: Late Pleistocene depositional cycles and syn-sedimentary tectonics on the central and south Adriatic shelf, Memorie della Società Geologica Italiana, 57, 516-526, 2002b.

Rohling, E. J., Jorissen, F. J., and De Stigter, H. C: 200 Year interruption of Holocene sapropel formation in the Adriatic Sea, J. Micropalaeontology, 16, 97-108, 1997.

Rothwell, R. G., Thomson, J., and Kähler, G.: Low-sea-level emplacement of a very large Late Pleistocene 'megaturbidite' in the western Mediterranean Sea, Nature, 392, 377-380, 1998.

Royden, L. E., Patacca, E., and Scandone, P.: Segmentation and configuration of subducted lithosphere in Italy: an important control on thrust-belt and foredeep-basin evolution, Geology, 15, 714-717, 1987.

Schwab W. C., Danforth, W. W., and Scanlon, K. M.: Tectonic and stratigraphic control on a giant submarine slope failure: Puerto Rico insular slope, in: Submarine landslides; selected studies in the U.S. Exclusive Economic Zone, edited by: Schwab, W. C., Lee, H. J., and Twichell, D. C., USGS Bull., 2002, 60-68, 1993.

Siani, G., Paterne, M., Michel, E., Sulpizio, R., Sbrana, A., Arnold, M., and Haddad, G.: Mediterranean Sea surface radiocarbon reservoir age changes since the last glacial maximum, Science, 294, 1917-1920, 2001.

Synolakis, C. E., Liu, P., Carrier, G., and Yeh, H.: Tsunamigenic seafloor deformation, Science, 278, 598-600, 1997.

Synolakis, C. E., Bardet, J. P., Borrero, J. C., Davies, H. L., Okal, E. A., Silver, E. A., Sweet, S., and Tappin, D. R.: The slump origin of the 1998 Papua New Guinea tsunami, Proceedings - Royal Society, Mathematical, Physical and Engineering Sciences, 458, 2020, 763-789, 8 April 2002.

Tappin, D. R., Matsumoto, T., Watts, P., et al.: Sediment slump likely caused Papua New Guinea tsunami, Eos (Transactions American Geophysical Union), 80, 329-340, 1999.

Tappin, D. R., Watts, P., McMurtry, G. M., Lafoy, Y., and Matsumoto, T.: The Sissano, Papua New Guinea Tsunami of July 1998 - offshore evidence on the source machanism, Mar. Geol., 175, 1-23, 2001.

Tinti, S. and Armigliato, A.: The use of scenarios to evaluate the tsunami impact southern Italy, Mar. Geology, 199, 221-243, 2003.

Tinti, S., Maramai, A., and Favalli, P.: The Gargano promontory: an important Italian seismogenetic-tsunamigenic area, Mar. Geology, 122, 227-241, 1995.

Tramontana, M., Morelli, D., and Colantoni, P.: Tettonica plioquaternaria del sistema sud-garganico (settore orientale) nel quadro evolutivo dell' Adriatico centro meridionale, Studi Geologici Camerti, 2, 467-473, 1995.

Trincardi, F. and Correggiari, A.: Muddy forced-regression deposits in the Adriatic basin and the composite nature of Quaternary sea level changes, in: Sedimentary Responses to Forced Regressions, edited by: Hunt, D. and Gawthorpe, R. L., Geological Society Spec. Publ., 172, 245-269, 2000.

Trincardi, F. and Field, M. E.: Collapse and flow of lowstand shelfmargin deposits: An example from the eastern Tyrrhenian Sea, Italy, Mar. Geo., 105, 77-94, 1992.

Trincardi, F., Cattaneo, A., Asioli A., Correggiari, A., and Langone, L.: Stratigraphy of the late-Quaternary deposits in the central Adriatic basin and the record of short-term climatic events, Memorie Istituto Italiano di Idrobiologia, 55, 39-70, 1996.

Trincardi, F., Cattaneo, A., Correggiari, A., Mongardi, S., Breda, A., and Asioli, A.: Submarine slides during sea level rise: two exemples from the eastern Tyrrhenian margin, in: Submarine Mass Movements and their Consequences, edited by: Locat, J. and Mienert, J., Kluver Acad. Publ., Dordrecht, The Netherlands, 469-478, 2003. 
Trincardi, F., Cattaneo, A., Correggiari, A., and Ridente, D.: Evidence of soft sediment deformation , fluid escape, sediment failure and regional weak layers within the late Quaternary mud deposits of the Adriatic Sea, Mar. Geo., 213, 91-120, 2004.

Twichell, D. C. and Roberts, D. G.: Morphology, distribution, and development of submarine canyons on the United States Atlantic continental slope between Hudson and Baltimore Canyons, Geology, 10, 408-412, 1982.

Twichell, D. C., Valentine, P. C., and Pratson, L. M.: Slope failure of carbonate sediment on the west Florida slope, in: Submarine landslides; selected studies in the U.S. Exclusive Economic Zone, edited by: Schwab W. C., Lee H. J., and Twichell D. C., USGS Bull., 2002, 60-68, 1993.
Verdicchio, G., Trincardi, F., and Asioli, A.: Mediterranean current deposits: an exemple fromk the Southwestern Adriatic Margin, Geological Society of London, Spec. Publ., in press, 2005.

Wilson, C. K., Long, D., and Bulat, J.: The Afen Slide - a multistaged slope failure in the Faeroe-Shetland Channel, in: Submarine Mass Movements and their Consequences, edited by: Locat, J. and Mienert, J., Kluver Acad. Publ., Dordrecht, The Netherlands, 357-366, 2003. 